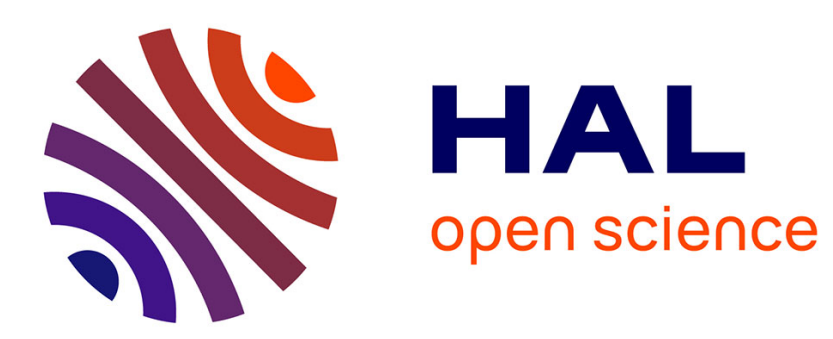

\title{
Insights into the biology and therapeutic implications of TNF and regulatory $T$ cells
}

Benoit L Salomon

\section{To cite this version:}

Benoit L Salomon. Insights into the biology and therapeutic implications of TNF and regulatory $\mathrm{T}$ cells. Nature Reviews Rheumatology, 2021, 10.1038/s41584-021-00639-6 . hal-03287990

\section{HAL Id: hal-03287990 \\ https://hal.sorbonne-universite.fr/hal-03287990}

Submitted on 16 Jul 2021

HAL is a multi-disciplinary open access archive for the deposit and dissemination of scientific research documents, whether they are published or not. The documents may come from teaching and research institutions in France or abroad, or from public or private research centers.
L'archive ouverte pluridisciplinaire HAL, est destinée au dépôt et à la diffusion de documents scientifiques de niveau recherche, publiés ou non, émanant des établissements d'enseignement et de recherche français ou étrangers, des laboratoires publics ou privés. 


\title{
Insights into the biology and therapeutic implications of TNF and regulatory T cells
}

\author{
Benoit L. Salomon ${ }^{\dagger}$
}

Sorbonne Université, INSERM, CNRS, Centre d'Immunologie et des Maladies Infectieuses (CIMI-Paris), F-75013, Paris, France.

†email: benoit.salomon@inserm.fr.

\begin{abstract}
Treatments that block tumour necrosis factor (TNF) have major beneficial effects in several autoimmune and rheumatic diseases, including rheumatoid arthritis. However, some patients do not respond to TNF inhibitor treatment and some rare occurrences of paradoxical disease exacerbation have been reported. These limitations on the clinical efficacy of TNF inhibitors can be explained by the differences between TNF receptor 1 (TNFR1) and TNFR2 signalling and by the diverse effects of TNF on multiple immune cells, including $\mathrm{FOXP}^{+}$regulatory $\mathrm{T}\left(\mathrm{T}_{\text {reg }}\right)$ cells. This basic knowledge sheds light on the consequences of TNF inhibitor therapies on $T_{\text {reg }}$ cells in treated patients and on the limitations of such treatment in the control of diseases with an autoimmune component. Accordingly, the next generation of drugs targeting TNF is likely to be based on agents that selectively block the binding of TNF to TNFR1 and on TNFR2 agonists. These approaches could improve the treatment of rheumatic diseases in the future.
\end{abstract}

\section{[H1] Introduction}

Tumour necrosis factor (TNF) is an inflammatory cytokine that is detected in the blood within minutes after an injury and has a major protective role in infectious diseases. In the late 1980s, TNF was detected in the joints of patients with rheumatoid arthritis (RA) $)^{1,2}$. A few years later, overexpression of TNF in transgenic mice was shown to induce autoimmune arthritis ${ }^{3}$. Agents that block this cytokine, termed TNF inhibitors, include monoclonal antibodies (mAbs) and soluble TNF receptors. Anti-TNF therapy was first tested in patients with sepsis without clear success and then repurposed for the treatment of RA in the early $1990 \mathrm{~s}^{1,2}$. TNF inhibitors are now widely used and have greatly improved the medical care of patients with RA, juvenile idiopathic arthritis, psoriasis, psoriatic arthritis and ankylosing spondylitis. Five original TNF 
inhibitors and numerous biosimilars have been approved, mostly for the treatment of arthritis, psoriasis or ankylosing spondylitis (Table 1). However, not all patients respond to TNF inhibitor treatment. One-third of patients with RA have to stop taking these drugs within the first year because of insufficient efficacy or adverse events ${ }^{4}$. About $20 \%$ of patients with psoriasis do not respond to treatment with a TNF inhibitor and around one-third of initial responders lose response over time ${ }^{5}$. Similar efficacy profiles are observed for patients with inflammatory bowel disease (IBD) ${ }^{6}$. Although this Review mainly focuses on the effects of TNF inhibitors in rheumatic diseases, particularly RA, I also discuss their effects and use in the treatment of other autoimmune and inflammatory diseases to illustrate the role and mechanisms of these agents in general.

Treatment with TNF inhibitors is also associated with adverse effects, such as infections, which are explained by the intrinsic anti-inflammatory effects of these agents. More intriguing (and counterintuitive) is the paradoxical exacerbation of pre-existing autoimmune disease or the development of new-onset autoimmune disease following TNF inhibitor therapy. Rarely, treated patients can develop lupus-like syndrome, vasculitis, antiphospholipid syndrome or sarcoidosis. For example, the reported prevalence of systemic lupus erythematosus (SLE) among recipients of TNF inhibitor therapy is $0.1-0.2 \%^{7-9}$. A few patients develop organ-specific autoimmune conditions, such as interstitial lung disease, optical neuritis, demyelinating neuropathy, multiple sclerosis (MS), psoriasis or autoimmune hepatitis, with the highest prevalence (2.00-5.00\%) reported for psoriasis and the lowest $(0.05-0.20 \%)$ for demyelinating disease. Several reviews have discussed in depth the spectrum of autoimmune diseases occurring in TNF inhibitor-treated patients $^{7-10}$, among which MS is of particular interest. In the late $1990 \mathrm{~s}$, before the increased risk of demyelinating neuropathy associated with TNF inhibitor treatment was known, two clinical trials investigated the efficacy of TNF inhibitors in MS. However, these drugs induced unexpected disease exacerbations that led to the worldwide contraindication of these drugs in these patients ${ }^{11,12}$. These observations sparked intense interest in elucidating why not all patients respond to TNF inhibitor therapy, developing biomarkers to predict response, and understanding why some treated patients develop paradoxical autoimmunity.

This Review focuses on the effects of TNF on inflammation and immunity. I describe the pro-inflammatory and regulatory roles of TNF, both of which are now well-established, and address the effects of this cytokine on diverse aspects of regulatory $\mathrm{T}\left(\mathrm{T}_{\mathrm{reg}}\right)$ cell biology, including their expansion, differentiation and suppressive function. Finally, I describe the effect of TNF inhibitors on $\mathrm{T}_{\text {reg }}$ cells and explore potential candidates for the next generation of drugs that target TNF or its receptors. Although TNF also has important roles in organogenesis and the 
development of lymphoid organs, protection of tissues in the nervous system, heart and joints ${ }^{13-15}$ and inhibition of tumorigenesis ${ }^{16}$, these topics are outside the scope of the present Review and will not be considered.

\section{[H1] The two Janus faces of TNF}

TNF has complex regulatory and pro-inflammatory effects in diseases with an autoimmune component ${ }^{13-15}$, such as $\mathrm{RA}^{17}$. This cytokine is produced under various inflammatory conditions by multiple cell types and exists in two forms: a soluble form that acts as a ligand, and a membrane-bound form that can act as either a ligand or a receptor ${ }^{18-20}$. Furthermore, TNF can induce multiple downstream signalling pathways ${ }^{9}$ as a result of binding to two different receptors, TNF receptor (TNFR) 1 and TNFR2, which are structurally related but have divergent biological properties. TNFR1 is broadly expressed whereas TNFR2 is expressed mostly by T cells, certain myeloid and endothelial cells and some cells of the central nervous system ${ }^{21,22}$.

The next sections describe the distinct functions of TNFR1 and TNFR2 and discuss the proinflammatory and anti-inflammatory effects of TNF on innate immune cells and lymphocytes, and present information on the cellular source of TNF.

\section{[H2] TNFR1 and TNFR2}

TNF is one of the most potent pro-inflammatory cytokines ${ }^{23}$, which explains the success of TNF inhibitor therapy in diseases with an inflammatory component. However, the paradoxical development or exacerbation of autoimmune disease in some patients treated with these drugs reveals the anti-inflammatory aspect of this cytokine, which is partly explained by effects downstream of TNFR2. Polymorphisms in TNFRSF1B, which encodes TNFR2, are frequently observed in patients with rheumatic diseases (RA, SLE, ankylosing spondylitis and systemic sclerosis) or IBD ${ }^{24}$. These mutations seem to alter the binding kinetics between TNF and TNFR2 and lead to inhibition of downstream NF-KB signalling, which suggests that TNFR2 signalling has a protective role in these diseases ${ }^{25}$. A single nucleotide polymorphism in TNFRSF1A, which encodes TNFR1, is specifically associated with an increased risk of MS. This allele results in the expression of a novel soluble form of TNFR1 that binds to and blocks TNF, and therefore mimics the MS-exacerbating effect of TNF inhibitor therapy ${ }^{26}$. Other mutations in TNFRSF1A that cause TNFR1 misfolding and endothelium reticulum stress are found in patients with periodic fevers ${ }^{27}$.

The differential functions of TNFR1 and TNFR2 in rheumatic and autoimmune diseases have been defined in mouse models. Generally, TNFR1-knockout mice have reduced disease 
severity whereas TNFR2-knockout mice develop exacerbated disease (Table 2). In addition, treatment with either TNFR1 antagonists or TNFR2 agonists suppresses disease symptoms in mouse models of arthritis and in mice with experimental autoimmune encephalomyelitis (EAE), a model of MS, further supporting a pathogenic role of TNFR1 and a protective role of TNFR2 (Table 2). A pathogenic role of TNFR1 and a protective role of TNFR2 have also been observed in mouse models of IBD, at least during the chronic phase of the disease $\mathrm{e}^{15,28}$. Thus, TNFR1 and TNFR2 seem to be pathogenic and protective, respectively, in some autoimmune and chronic inflammatory diseases.

\section{[H2] Effects of TNF on innate immunity}

\section{[H3] Pro-inflammatory effects.}

The pro-inflammatory effects of TNF on innate immunity involve several distinct mechanisms

(Figure 1). TNF is one of the main drivers of acute inflammation because it activates endothelial cells, induces chemokine release and promotes intense and early (within hours) recruitment of neutrophils and monocytes, via both TNFR1 and TNFR2 $2^{29,30}$. Acute inflammation is also attributed to the TNF-mediated activation of canonical NF-KB signalling, which leads to the early induction of inflammatory cytokines, including TNF itself, IL-6, IL-8 and IL-1 $\beta^{14}$. TNF also sustains inflammation through the activation of receptor-interacting protein kinase (RIPK) 1 and RIPK3, which promote necroptosis and the release of inflammatory compounds termed damage-associated molecular patterns (DAMPs) ${ }^{31}$. In addition, via TNFR1 signalling, TNF promotes innate immunity by favouring the maturation of dendritic cells $\mathrm{s}^{32,33}$.

\section{[H3] Regulatory effects.}

The immunoregulatory functions of TNF are likely to involve multiple mechanisms (Figure 1). TNF might promote the extra-adrenal production of immunoregulatory glucocorticoids ${ }^{34}$ and inhibit haematopoiesis ${ }^{35}$. TNF also stimulates innate immunosuppressive cells (via TNFR2) and activates mesenchymal stem cells, which produce increased levels of immunosuppressive prostaglandin $\mathrm{E} 2\left(\mathrm{PGE}_{2}\right)$, as has been shown in synovial fluid from patients with $\mathrm{RA}^{36,37}$. TNF also promotes immunosuppression by favouring either the differentiation or the suppressive function of myeloid-derived suppressor cells via increasing their production of reactive oxygen species, arginase 1 and inducible nitric oxide synthase $\mathrm{s}^{38-42}$.

\section{[H3] Effects on dendritic cells, monocytes and macrophages.}

Although TNF seems to favour the production of T-bet and IL-12 by dendritic cells ${ }^{43}$, other 
studies suggest that the presence of TNF inhibits the production of $\mathrm{p} 40$ (the common chain of IL12 and IL-23) by dendritic cells, macrophages and monocytes ${ }^{44-46}$. These divergent findings could be explained by differential actions of TNF depending on the maturation stage and type of both antigen presenting cells and dendritic cell subsets.

In addition, TNF can either promote or inhibit macrophage activation, effects that are both probably mediated by TNFR1 (reviewed elsewhere ${ }^{14}$ ). The early response of macrophages to incubation with TNF, observed after a few hours, is both NF-KB-dependent and MAPKdependent and involves the expression of genes encoding various inflammatory molecules and cytokines. This initial response is followed (after 24 hours) by a state of desensitization, also called cross-tolerance or endotoxin tolerance. Desensitized (also termed tolerized) macrophages are unable to produce inflammatory factors when stimulated by potent activators such as Tolllike receptor ligands. The mechanism of desensitization involves NF-KB inhibition following activation of glycogen synthase kinase 3 (GSK3) and TNF-induced protein 3 (TNFAIP3) ${ }^{47}$. Tolerized macrophages have a transiently reduced capacity to produce IL-12 and IL-23, which are pro-inflammatory ${ }^{46,48}$. The physiological role of cross-tolerance is probably the prevention of life-threatening inflammation in the context of overwhelming macrophage activation by pathogens and Toll-like receptor ligands. Ultimately, after prolonged incubation with TNF, specifically in the presence of type 1 interferons, macrophages overcome this desensitized state and recover their inflammatory function by modifying their metabolism and epigenetic status 49,50 .

\section{[H2] Effects of TNF on lymphocytes}

\section{[H3] Pro-inflammatory effects.}

TNF can either promote or suppress immunity through its differential effects on lymphocytes (Figure 1). The pro-inflammatory effects of TNF result from co-stimulation of T cells, mainly via TNFR2. TNF activates NF-KB and AKT signalling pathways that lead to increased T cell proliferation and survival, which are associated with increased levels of BCL2, BCLXL, IL-2 and survivin ${ }^{51-56}$. However, the co-stimulatory effect of TNF binding to TNFR2 on conventional $\mathrm{T}$ cells seems to be of marginal importance compared with its strong effect on $\mathrm{T}_{\text {reg }}$ cells ${ }^{57}$, which is extensively discussed below.

\section{[H3] Regulatory effects.}

Although one report suggests that TNF promotes the expression of IL-10 by B regulatory ( $\left.\mathrm{B}_{\text {reg }}\right)$ cells $^{58}$, much more is known about the inhibitory effects of TNF on T cells. Prolonged exposure 
to TNF attenuates $\mathrm{T}$ cell receptor signalling by impairing store-operated calcium influx ${ }^{59,60}$ and also favours T cell exhaustion; in one report, TNF blockade during chronic infection with lymphocytic choriomeningitis virus abrogated the inhibitory gene expression signature ${ }^{61}$. TNF is able to induce activation-induced cell death via TNFR1 engagement ${ }^{62}$. Interestingly, TNFR2 signalling also seems to increase T-cell apoptosis by interfering with signalling pathways downstream of TNFR $1^{63}$. However, TNFR2-dependent cell death might specifically occur in autoreactive T cells, which have altered TNFR2 signalling ${ }^{25,62,64-68}$. Cross-talk between TNFR1 and TNFR2 signalling is discussed in more detail in subsequent sections.

TNF also inhibits the differentiation of $\mathrm{T}_{\mathrm{H}} 17$ cells by increasing IL-2 production ${ }^{69}$, and decreases IL-17 production by conventional $\mathrm{T}$ cells and effector $\mathrm{T}_{\text {reg }}$ cells via activation of TNFAIP $3^{70,71}$. This mechanism might explain the increase in numbers of $T_{H} 17$ cells described in TNFR1-knockout mice or after treatment with TNF inhibitors in mouse models of RA and psoriasis ${ }^{44-46,72,73}$. A similar increase in $T_{H} 17$ cells has been reported specifically in nonresponding patients with RA treated with TNF inhibitors ${ }^{44,74}$. Interestingly, these non-responding patients showed a $T_{H} 1$-mediated and $\mathrm{T}_{\mathrm{H}} 17$-mediated immune response against the TNF inhibitor, which might have precipitated their lack of clinical response ${ }^{75}$. Finally, in the late 2000s, regulatory properties of TNF were proposed to result from its effects on $\mathrm{T}_{\text {reg }}$ cells. These mechanisms are extensively discussed below.

\section{[H2] Cellular sources of TNF}

Multiple cell types are able to produce TNF, but the immune cells that produce this cytokine in the highest amounts are myeloid cells and activated $\mathrm{T}$ cells ${ }^{76}$. The role of TNF produced by these two cell types in rheumatic and autoimmune diseases has been investigated using genetically modified mice with conditional knock-out of TNF only in myeloid cells or only in T cells. In mice with collagen-induced arthritis, conditional knockout of TNF in myeloid cells leads to reduced disease severity, showing that the TNF produced by these cells contributes to the pathology. By contrast, mice with TNF-deficient T cells have exacerbated arthritis, suggesting a protective role of the TNF produced by $\mathrm{T}$ cells ${ }^{77}$. Similarly, mice with EAE and TNF-deficient myeloid cells have attenuated disease, which is either delayed in onset or reduced in severity depending on the model ${ }^{76,78}$. Finally, the role of TNF produced by B cells has been analyzed in mice with TNF-deficient B cells. These mice have reduced arthritis and reduced levels of autoantibodies ${ }^{77}$.

\section{[H2] TNF structure and signalling}




\section{[H3] Soluble and transmembrane TNF.}

Crystallographic studies show that trimers of TNF interact with trimers of either TNFR1 or TNFR2 ${ }^{79,80}$. This trimeric association of the cytokine with its receptor is characteristic of the TNF superfamily and is critical for downstream signalling ${ }^{63,81}$.

TNF is initially produced as a transmembrane molecule that can be processed by disintegrin and metalloproteinase domain-containing protein 17 (also known as TNF converting enzyme (TACE)) encoded by the $A D A M 17$ gene ${ }^{82}$. Thus, activated myeloid and $\mathrm{T}$ cells produce transmembrane TNF and secreted soluble TNF, which are both biologically active ${ }^{77,83,84}$. The role of soluble TNF in the pathophysiology of rheumatic and autoimmune diseases has been assessed in mice engineered to express a TNF protein that cannot be cleaved by TACE. Thus, these mice produce normal levels of transmembrane TNF but no soluble TNF ${ }^{83}$. Importantly, such mice do not develop EAE or arthritis, showing that soluble TNF but not transmembrane TNF contributes to these diseases ${ }^{77,83,84}$. By contrast, mice with global deletion of TNF (full knock-out) still develop EAE, which suggests that transmembrane TNF has protective effects in the disease ${ }^{83}$.

Despite a similarly high binding affinity for its two receptors, trimeric soluble TNF triggers TNFR1 signalling much more efficiently than it does TNFR2 signalling ${ }^{85}$. Although this observation requires further confirmation, TNFR1 signalling is usually considered to be triggered by both soluble and transmembrane TNF whereas TNFR2 signalling is preferentially triggered by transmembrane $\mathrm{TNF}^{86}$. These observations suggest that soluble TNF (notably that produced by myeloid cells at the onset of a rheumatic or autoimmune disease) binds to TNFR1 to promote inflammation and precipitate the disease, whereas transmembrane TNF (probably that expressed by both myeloid and $\mathrm{T}$ cells) has regulatory effects mostly derived from triggering TNFR2. These observations might have implications for the use of TNF inhibitors. For example, etanercept (a TNFR2-Fc fusion protein) can efficiently block soluble TNF (as well as $\alpha 3$ and $\alpha 2 \beta 1$ lymphotoxins) but not transmembrane TNF, whereas anti-TNF monoclonal antibodies block both soluble and transmembrane $\mathrm{TNF}^{82}$. This concept also has implications for the design of next-generation TNF inhibitors, as discussed below.

\section{[H3] TNFR1 and TNFR2 signalling pathways.}

TNFR1 and TNFR2 signalling pathways are complex and have been extensively reviewed elsewhere ${ }^{14,15,63,86}$. Accordingly, only the pathways most relevant to this review are outlined here. Most of the available knowledge has been obtained in cell lines and non-immune cells and deserves further investigation to confirm its relevance in immune cells. 
Upon binding of trimeric TNF to TNFR1, the cytoplasmic tail of the receptor recruits the adaptor protein TNFR1-associated death domain (TRADD) via its death domain. TRADD can then interact with other adaptor proteins, such as TNF receptor associated factor 2 (TRAF2), and kinases, such as receptor-interacting serine/threonine-protein kinase 1 (RIPK1) or cellular inhibitor of apoptosis (cIAP) 1 and cIAP2. The resulting molecular complex, named complex 1, is able to phosphorylate and ubiquitinate several other molecules, ultimately leading to potent activation of canonical NF-KB and MAPK pathways. Members of these pathways, such as c-Jun $N$-terminal kinase (JNK) and $\mathrm{p} 38$, in turn, activate AP1 complex ${ }^{14,15,63,86}$. This complex-1dependent signalling pathway favours cell proliferation and survival. Alternatively, TNFR1 and TRADD interact with the Fas associated death domain (FADD) adaptors RIPK1 and RIPK3, forming the complex 2 interactome, which is able to induce cell death: either apoptosis (via caspase 8 activation) or necroptosis (via mixed lineage kinase domain-like (MLKL) protein activation) $)^{14,15,63,86}$.

Complex 1 and complex 2 are downstream effectors of TNFR1 signalling. Complex 1 is probably involved in most of the effects of TNF on dendritic cells and macrophages, including activation of inflammatory target genes and production of inflammatory cytokines. Complex 2 is involved in TNF-dependent, activation-induced cell death and the formation of inflammationdependent DAMPs.

The signal transduction pathway downstream of TNFR2 lacks a death domain and involves different adaptors. Binding of transmembrane TNF to TNFR2 recruits TRAF1 or TRAF2 adaptors to this receptor, leading to activation of cIAP1 or cIAP2 kinases and activation of canonical and non-canonical NF-KB, JNK and AKT pathways that promote cell proliferation and survival ${ }^{14,15,63,86-88}$. These pathways are likely to be involved in the TNF-dependent activation of mesenchymal stem cells and myeloid-derived stem cells as well as T cell costimulation. TRAF2 recruitment to TNFR2 also decreases the amount of cytoplasmic TRAF2, which interferes with TNFR1 signalling by favouring the formation of (cell death-promoting) complex 2 to the detriment of (survival-promoting) complex $1^{63}$. This cross-talk between TNFR1 and TNFR2 signalling pathways seems to be responsible for TNFR2-dependent T cell death ${ }^{89}$.

\section{[H3] TNF reverse signalling.}

Reverse (extracellular to intracellular) signalling induced by transmembrane TNF has been described but remains poorly documented. This phenomenon is only outlined here as it has been reviewed elsewhere ${ }^{18-20}$. In this context, TNFR1 or TNFR2 can act as ligands for transmembrane TNF, which can function as a cell receptor transducing a signal in several different situations. 
For example, TNFR2-expressing T cells promote the increased expression of TNF in monocytes and/or macrophages via transmembrane TNF, a phenomenon that has been observed in the joints of patients with RA. Also, TNFR1-expressing endothelial cells induce cross-tolerance in monocytes and/or macrophages via transmembrane TNF. Finally, TNF inhibitors are also able to bind to transmembrane TNF and thereby induce the apoptosis of transmembrane TNF-expressing cells; this phenomenon has been observed for instance in T cells and synovial macrophages from patients with RA ${ }^{90,91}$. The mechanism of TNF reverse signalling involves increased intracellular levels of calcium and TGF- $\beta$ and activation of the MAPK-ERK pathway. However, the in vivo relevance of reverse signalling is difficult to assess because this phenomenon has been poorly described. I consider that reverse signalling might contribute to the spectrum of effects of TNF and might have an important role in inducing cross-tolerance of macrophages and in the death of transmembrane TNF-expressing cells induced by administration of TNF inhibitors.

\section{[H2] Integrative view of TNF functions}

Here, I present a simplified and integrated view of what I believe is the major role of TNF in immunity (Figure 1). TNF is one of the most potent inflammatory cytokines owing to its capacity to activate endothelial cells, neutrophils, macrophages and dendritic cells, leading to leukocyte recruitment and massive release of inflammatory cytokines at sites of inflammation. Most of these pro-inflammatory phenomena are mediated by TNFR1 signalling. Besides its proinflammatory functions, TNF also has anti-inflammatory (regulatory) functions, although their role and mechanisms in immunity are yet to be clarified. The regulatory functions involve TNFdependent activation of suppressive cells, such as mesenchymal stem cells, myeloid-derived stem cells and of course $T_{\text {reg }}$ cells (which are extensively discussed below). TNF might also promote death or exhaustion of $\mathrm{T}$ cells and inhibit pathogenic $\mathrm{T}_{\mathrm{H}} 17$ cells. Most of these regulatory phenomena are mediated by TNFR 2 signalling.

The end result of TNF blockade depends on the type of autoimmune disease present and the timing of treatment. Blocking the interaction between TNF and TNFR1 led to increased numbers of pathogenic $T_{H} 1$ and $T_{H} 17$ cells in mouse models of arthritis and psoriasis ${ }^{44-46,72,73}$. This increase was associated with exacerbation of psoriasis (as might logically be expected) but surprisingly with attenuation of arthritis because this treatment also blocked the migration of pathogenic T cells to the joints ${ }^{46}$. Similarly, patients with RA treated with TNF inhibitors have increased levels of circulating $\mathrm{T}_{\mathrm{H}} 1$ and $\mathrm{T}_{\mathrm{H}} 17$ cells $^{44,74,75}$, which could explain some of the paradoxical inflammation observed in a subset of these patients. The effects of TNF blockade could also depend on the timing of treatment in relation to the course of disease. To investigate 
the role of TNF signalling via TNFR2 in a model of collagen-induced arthritis, TNFR1-knockout mice were treated with TNF on either days $2-20$ or days $22-40$ after disease induction ${ }^{92}$. Interestingly, early TNF treatment led to disease exacerbation whereas late TNF treatment led to attenuation of arthritis. An opposite effect of TNF that is similarly dependent on the stage of disease progression has been documented in non-obese diabetic mice; TNF seems to exacerbate diabetes in young mice by activating dendritic cells and to attenuate it in adult mice by inhibiting conventional $\mathrm{T}$ cells and promoting $\mathrm{T}_{\text {reg }}$ cell activation ${ }^{59,93-95}$.

\section{[H1] Effects of TNF on $T_{\text {reg }}$ cells}

$\mathrm{T}_{\text {reg }}$ cells are master regulators of autoimmune diseases. Mice and humans that are genetically deficient in $\mathrm{T}_{\text {reg }}$ cells die soon after birth from a massive and systemic autoimmune syndrome, which reveals the critical role of these cells in the suppression of autoimmunity ${ }^{96}$. Functional or quantitative defects of $\mathrm{T}_{\text {reg }}$ cells have been reported in many human autoimmune diseases ${ }^{97}$. Other indirect evidence supports the concept that $\mathrm{T}_{\text {reg }}$ cells contribute to human autoimmune diseases. For instance, some biomarkers of disease activity, such as $\mathrm{C}$ reactive protein levels, are inversely correlated with $\mathrm{T}_{\text {reg }}$ cell proportion in patients with $\mathrm{RA}^{98}$ or $\mathrm{IBD}^{99,100}$. Moreover, $\mathrm{T}_{\text {reg }}$ cell transfer seems to have beneficial effects in patients with various autoimmune diseases ${ }^{101}$.

Transcriptomic analyses that compared $\mathrm{T}_{\text {reg }}$ with conventional $\mathrm{T}$ cells in lymphoid tissues showed that several members of the TNFR superfamily, including TNFR2, TNFR superfamily member 4 (OX40), TNFR superfamily member 9 (41BB) and TNFR superfamily member 18 (GITR) are included in the $\mathrm{T}_{\text {reg }}$ cell signature ${ }^{102}$. These molecules are further upregulated upon stimulation of either the T cell receptor (TCR) or T cell-specific surface glycoprotein CD28 and are therefore preferentially expressed by effector $T_{\text {reg }}$ cells rather than resting $T_{\text {reg }}$ cells ${ }^{103,104}$. At steady state, $30 \%$ of $\mathrm{T}_{\text {reg }}$ cells express TNFR 2 and most of this subset are effector $\mathrm{T}_{\text {reg }}$ cells that have a stronger suppressive function in vitro than do TNFR2- resting $\mathrm{T}_{\text {reg }}$ cells ${ }^{105,106}$. Thus, TNFR2 belongs to the $T_{\text {reg }}$ cell signature and is a marker of highly suppressive $T_{\text {reg }}$ cells.

\section{[H2] Effects on $T_{\text {reg }}$ cell expansion}

Expansion is defined as an increase in cell numbers, and results from a combination of increased proliferation, prolonged survival and phenotypic stability. TNFR2 signalling seems to expand $\mathrm{T}_{\text {reg }}$ cells by increasing all three of these factors.

Initially, TNF and/or TNFR2 co-stimulation were shown to increase $\mathrm{T}_{\text {reg }}$ cell proliferation in mice ${ }^{22,107}$. Our group and others showed that effector $\mathrm{T}$ cells, in particular $\mathrm{T}_{\mathrm{H}} 17$ cells, are a major source of the TNF that induces this increase in the $\mathrm{T}_{\text {reg }}$ cell population in vivo ${ }^{108-110}$. 
Similar findings were obtained for human $\mathrm{T}_{\text {reg }}$ cells $\mathrm{s}^{84,111,112}$. TNF can also substantially prolong $\mathrm{T}_{\text {reg }}$ cell survival ${ }^{103}$. Indirect evidence indicates that TNFR2 signalling also maintains FOXP3 expression, which increases $\mathrm{T}_{\text {reg }}$ cell phenotypic stability and therefore their long-term expansion $^{112-115}$.

In many of these in vitro studies, soluble TNF was capable of boosting $\mathrm{T}_{\text {reg }}$ cell expansion. Although transmembrane TNF has a stronger effect than soluble TNF on induction of TNFR2 signalling ${ }^{85}$, strong evidence indicates that soluble TNF can indeed stimulate the expansion of $\mathrm{T}_{\text {reg }}$ cells by binding to TNFR2. Furthermore, TNFR1 expression has not been detected on $\mathrm{T}_{\text {reg }}$ cells (unlike TNFR2 expression) ${ }^{22}$. The expansion-promoting effect of soluble TNF on $\mathrm{T}_{\text {reg }}$ cells was lost in TNFR2-deficient $\mathrm{T}_{\text {reg }}$ cells and when TNFR2, but not TNFR1, was blocked $^{113}$. Finally, treatment with TNF or TNFR2 agonists induced similar co-stimulation of $\mathrm{T}_{\text {reg }}$ cells ${ }^{111}$. The capacity of soluble TNF to efficiently induce TNFR2 signalling could be explained by the use of high concentrations of this cytokine or the presence of TNF aggregates with crosslinking properties in the preparations. TNFR2 agonists, which are either multimers of mutated TNF or mAbs that bind only to TNFR2 (discussed in more detail below), strongly costimulate $\mathrm{T}_{\text {reg }}$ cells in both mice and humans $\mathrm{s}^{57,103,111,116-118}$. In a study of pre-activated $\mathrm{T}$ cells, TNFR2 co-stimulation strongly increased the proliferation of $\mathrm{T}_{\text {reg }}$ but had no effect on conventional $\mathrm{T}$ cells $\mathrm{s}^{57}$. The capacity of TNFR 2 co-stimulation to promote $\mathrm{T}_{\mathrm{reg}}$ cell expansion was confirmed in vivo in animals treated with TNFR2 agonists ${ }^{86,117,119-121}$.

Although very little is known about TNFR2 signal transduction in $\mathrm{T}_{\text {reg }}$ cells, transcriptomic analyses showed that binding of TNF to TNFR2 on purified mouse or human $\mathrm{T}_{\text {reg }}$ cells induced a gene expression signature indicative of NF- $\mathrm{\kappa B}$ pathway activation ${ }^{103,122}$. More precisely, TNFR2 signalling induced nuclear translocation and binding of RelA to its DNA target sequence, which suggests that the canonical NF- $\kappa$ B pathway is activated by TNFR2 signalling in $\mathrm{T}_{\text {reg }}$ cells. Importantly, the increased proliferation and prolonged survival of $\mathrm{T}_{\text {reg }}$ cells induced by TNFR2 triggering was severely attenuated in RelA-deficient $\mathrm{T}_{\text {reg }}$ cells ${ }^{103,104}$. Some evidence also suggests that the non-canonical NF- $\mathrm{kB}$ pathway is also activated by TNFR2 signalling in $T_{\text {reg }}$ cells but this observation has to be treated with caution because these assays were conducted on a cell population with low $\mathrm{T}_{\text {reg }}$ cell purity ${ }^{123}$. Other data suggest that TNFR2 signalling induces activation of the MAPK pathway, notably via $338^{124,125}$. TNFR2-mediated costimulation of $\mathrm{T}_{\text {reg }}$ cells also induced a glycolytic switch associated with activation of mammalian target of rapamycin complex 1 (mTORC1) signalling via phosphoinositide-3 kinase (PI3K), although the signalling pathway connecting TNFR2 to PI3K was not identified ${ }^{57}$. 
Overall, strong evidence indicates that the boost in $\mathrm{T}_{\text {reg }}$ cell numbers induced by TNFR2 signalling involves activation of the canonical NF- $\mathrm{kB}$ pathway. The role of the other signalling pathways mentioned here requires further documentation.

\section{[H2] Effects on $\mathbf{T}_{\text {reg }}$ suppressive function}

The effects of TNF on the suppressive function of mouse and human $\mathrm{T}_{\text {reg }}$ cells have been assessed in vitro (Table 3). The first of these studies showed no effect of low-dose ( $\leq 5 \mathrm{ng} / \mathrm{ml}$ ) TNF in human cells ${ }^{98}$. Five subsequent reports showed that treatment with TNF, usually at a high dose $(50 \mathrm{ng} / \mathrm{ml})$, reduced the suppression of conventional $\mathrm{T}$ cell activation by human $\mathrm{T}_{\text {reg }}$ cells ${ }^{122,126-129}$. By contrast, in vitro studies performed in mouse cells showed that the presence of high amounts of TNF either had no effect or even increased $\mathrm{T}_{\text {reg }}$ cell-mediated suppression of conventional $\mathrm{T}$ cell activation ${ }^{22,107}$. Moreover, other evidence also suggests that TNF does not inhibit $\mathrm{T}_{\text {reg }}$ cell-mediated suppression of conventional $\mathrm{T}$ cells, and might even increase it. For instance, administration of a TNFR2 agonist to mice with graft versus host disease (GvHD) or collagen-induced arthritis promoted $\mathrm{T}_{\text {reg }}$ cell expansion and had a therapeutic effect ${ }^{117,119,121}$. Also, treatment of cultured $\mathrm{T}_{\text {reg }}$ cells with TNF increased their capacity to suppress colitis or GvHD after transfer ${ }^{103,130}$, whereas TNFR2-deficient $T_{\text {reg }}$ cells had a reduced capacity to suppress colitis or GvHD ${ }^{114,131}$. However, these observations provide only indirect evidence that $\mathrm{TNF}$ either had no effect on or increased $\mathrm{T}_{\text {reg }}$ cell suppressive function in mice. Indeed, this cytokine might influence other parameters of $\mathrm{T}_{\text {reg }}$ cell biology (such as proliferation, survival, functional stability or migration). Interestingly, EAE was exacerbated in genetically modified mice in which TNFR2 was ablated only in $\mathrm{T}_{\text {reg }}$ cells. Ablation of TNFR2 in $\mathrm{T}_{\text {reg }}$ cells seems to decrease their suppressive function specifically in the inflamed central nervous system ${ }^{132}$. In this context, the expression of TNFR2 by $\mathrm{T}_{\text {reg }}$ cells might be essential for their suppressive function and their capacity to control EAE.

Our group also performed an analysis of the suppressive capacity of $\mathrm{T}_{\text {reg }}$ cells from numerous different human donors under three different $\mathrm{T}$ cell activation conditions. We consistently found that TNF (added either before or during the suppression assay) either had no effect on or even slightly increased the suppressive activity of human $\mathrm{T}_{\text {reg }}$ cells ${ }^{133}$. The preservation of $\mathrm{T}_{\text {reg }}$ cell suppressive activity after TNFR2 co-stimulation (achieved using a TNFR2 agonist) in humans has also been confirmed ${ }^{57}$.

Several factors might account for the contrasting findings in mouse and human cells. First, as none of the available markers can exclusively characterize the population of human $\mathrm{T}_{\text {reg }}$ cells, the purified $\mathrm{T}_{\mathrm{reg}}$ cell populations used in some of these studies might still have some level 
of contamination by activated conventional T cells, especially when only CD4 and CD25 expression was used to sort the cells ${ }^{134}$. Second, given the high inter-individual variability in $\mathrm{T}_{\text {reg }}$ cell phenotypes, responses to TNF and suppressive activity, it is important to collect data from a sufficiently large sample of individuals. Finally, a $\mathrm{T}_{\text {reg }}$ cell functional defect identified in a suppression assay could be due either to intrinsic $\mathrm{T}_{\text {reg }}$ cell dysfunction or to the presence of contaminating conventional $\mathrm{T}$ cells that are resistant to $\mathrm{T}_{\text {reg }}$ cell suppression. This last point is critical with regard to the effects of TNF. Indeed, in addition to its proliferation-promoting effect on $\mathrm{T}_{\text {reg }}$ cells, TNF not only increases the proliferation of conventional $\mathrm{T}$ cells ${ }^{51,53,133}$ but also increases their resistance to $T_{\text {reg }}$ cell-mediated suppression ${ }^{135}$. In several studies performed in human cells, TNF was present during the suppression assays and might act on any contaminating conventional $\mathrm{T}$ cells, which would impair the evaluation of $\mathrm{T}_{\text {reg }}$ cell suppressive function (Table 3). Accordingly, pre-incubation of the $T_{\text {reg }}$ cells with TNF is appropriate before testing their capacity to suppress conventional T cells.

Another critical point is the choice of parameter used to assess the activation of conventional $\mathrm{T}$ cells. As TNF strongly increases $\mathrm{T}_{\text {reg }}$ cell proliferation (and possibly also cytokine production), measuring the activation of only the conventional $\mathrm{T}$ cells within the population is critical. This measurement can be done by analyzing fluorescent marker dilution or assessing intracellular cytokine production using flow cytometry techniques such as fluorescence-activated cell sorting (FACS). Researchers should not use thymidine incorporation or enzyme-linked immunosorbent assays (ELISA) to measure the proliferation or cytokine production of the whole cell population, which includes both conventional $\mathrm{T}$ cells and $\mathrm{T}_{\text {reg }}$ cells. For this reason, to accurately determine whether TNF alters the suppressive function of $\mathrm{T}_{\text {reg }}$ cells, we recommend that TNF is added only during the pre-incubation phase (that is, before the suppressive assay), and that activation of only the conventional T cells is measured by FACS. The absence of these two precautionary measures in some of the reports claiming that TNF inhibits $\mathrm{T}_{\text {reg }}$ cell suppressive activity in humans undermines their conclusions (Table 3 ).

To conclude, weak evidence indicates that TNF is able to either inhibit or increase the suppressive activity of $\mathrm{T}_{\text {reg }}$ cells. After careful analyses of the data from in vitro assays, I would say that TNF has no or only a minor effect on $\mathrm{T}_{\text {reg }}$ cell suppressive function in this context. However, this cytokine seems to have an essential role in stimulation of $\mathrm{T}_{\text {reg }}$ cell function in some conditions associated with inflammation.

The data derived from in vitro studies of mechanisms underlying the suppressive activity of $\mathrm{T}_{\text {reg }}$ cells reflect only the tip of the iceberg, as only two or three suppressive mechanisms have been analyzed in these studies to date. However, it is now well established that $\mathrm{T}_{\text {reg }}$ cells in vivo 
are able to use a wide range of suppressive mechanisms depending on their tissue localization and the type of inflammation present ${ }^{136,137}$. The suppressive activity of $\mathrm{T}_{\text {reg }}$ cells also involves many different effector molecules. Some have been thoroughly studied and shown to be essential for aspects of $\mathrm{T}_{\text {reg }}$ cell suppression, such as cytotoxic T-lymphocyte protein 4 (CTLA4) and IL$10^{138}$. FOXP3 expression is also critical because its loss leads to loss of $\mathrm{T}_{\text {reg }}$ cell function ${ }^{138}$, but no single marker has been shown to easily quantify the level of $\mathrm{T}_{\text {reg }}$ cell suppression.

Several mechanisms have been suggested to explain how TNF might increase the suppressive function of $\mathrm{T}_{\text {reg }}$ cells in mice. TNF promotes full differentiation of effector $\mathrm{T}_{\text {reg }}$ cells by stimulating NF-KB, which might increase some of these cells' suppressive functions ${ }^{103,104}$. TNF also synergizes with IL-2 to increase the expression of CD25 (the IL-2 receptor $\alpha$-chain) and FOXP3 ${ }^{22,133}$. Moreover, TNF increases the IL-2-induced phosphorylation of STAT5 ${ }^{22}$ and limits the loss of FOXP3 expression in cultured cells by preventing re-methylation of the Foxp3 promoter $^{113,115}$. Thus, TNF might increase $\mathrm{T}_{\text {reg }}$ cell suppression and stability by favouring both phosphorylation of STAT5 and FOXP3 expression, which are key determinants of these $\mathrm{T}_{\text {reg }}$ cell features $^{139,140}$. Finally, TNF limits IL-17 production by $\mathrm{T}_{\text {reg }}$ cells by activating TNFAIP3 ${ }^{71}$.

Other mechanisms have been proposed to explain how TNF might decrease $\mathrm{T}_{\text {reg }}$ cell function. TNF decreases FOXP3 expression by increasing the expression of deleted in breast cancer 1 (DBC1) and miR-34a, which respectively promote FOXP3 degradation and reduce FOXP3 transcription and translation ${ }^{128,141,142}$. Alternatively, TNF might increase the expression of serine/threonine-protein phosphatase PP1, which dephosphorylates FOXP3, thereby decreasing its effect on $\mathrm{T}_{\text {reg }}$ cell suppressive function ${ }^{126}$.

\section{[H2] Effects on $T_{\text {reg }}$ cell differentiation}

The population of FOXP3 ${ }^{+} \mathrm{T}_{\text {reg }}$ cells is composed of thymic $\mathrm{T}_{\text {reg }}$ cells, which acquire their $\mathrm{T}_{\text {reg }}$ cell state during their development in the thymus, and peripheral $\mathrm{T}_{\text {reg }}$ cells, which acquire their $\mathrm{T}_{\text {reg }}$ cell state during peripheral differentiation of mature naive conventional $\mathrm{T}$ cells. Finally, induced $\mathrm{T}_{\text {reg }}$ cells can be differentiated in vitro from naive conventional $\mathrm{T}$ cells by TCR stimulation in the presence of IL- 2 and TGF- $\beta$. Thus, induced $\mathrm{T}_{\text {reg }}$ cells are the in vitro counterpart of peripheral $\mathrm{T}_{\text {reg }}$ cells.

However, whereas TNF alone has no effect on thymic $\mathrm{T}_{\text {reg }}$ cell differentiation, experiments in mice show that TNF inhibits the differentiation of induced $\mathrm{T}_{\text {reg }}$ cells, whereas treatment with TNF inhibitors increased the differentiation of induced $\mathrm{T}_{\text {reg }}$ cells $\mathrm{s}^{143,144}$. This inhibitory effect of TNF was also observed on peripheral $\mathrm{T}_{\text {reg }}$ cells in vivo. In mice with EAE, injection of anti-TNF or anti-TNFR2 mAbs at the time of disease induction led to reduced 
disease severity, which was associated with an increased proportion of $\mathrm{T}_{\text {reg }}$ cells and evidence of increased peripheral $\mathrm{T}_{\text {reg }}$ cell differentiation ${ }^{144}$. Two other papers do not support this observation and even suggest that the TNF-TNFR2 axis promotes the differentiation of induced $\mathrm{T}_{\text {reg }}$ and peripheral $\mathrm{T}_{\text {reg }}$ cells ${ }^{28,73}$. However, the design of these two studies meant that contaminating natural $\mathrm{T}_{\text {reg }}$ cells were present in the starting inoculum, and thus treatment with TNF might boost the expansion of these contaminating cells rather than increase the differentiation of induced $\mathrm{T}_{\text {reg }}$ cells ${ }^{28,73}$. TNF does not seem to affect thymic $T_{\text {reg }}$ cell differentiation at steady state, because mice lacking TNFR2 have normal thymic $T_{\text {reg }}$ cell numbers. However, ablation or neutralization of TNFR2 combined with ablation or neutralization of two other members of the TNFR superfamily, namely OX40 and GITR, led to reduced differentiation of thymic $\mathrm{T}_{\text {reg }}$ cells ${ }^{145}$. Overall, whereas the effect of TNF on $\mathrm{T}_{\text {reg }}$ cell differentiation is still open to discussion, an excess of TNF seems to impair the differentiation of induced $\mathrm{T}_{\text {reg }}$ cells and peripheral $\mathrm{T}_{\text {reg }}$ cells in mice.

In humans, the inhibition of $\mathrm{T}_{\text {reg }}$ cell differentiation by $\mathrm{TNF}$ was first observed in patients with RA. TNF inhibitor treatment increased the in vitro differentiation of induced $\mathrm{T}_{\text {reg }}$ cells derived from patients with RA but not those from healthy controls ${ }^{146}$. This observation explained why blood samples from patients with RA treated with infliximab had an increased proportion of $\mathrm{T}_{\text {reg }}$ cells, which might result from increased differentiation of peripheral $\mathrm{T}_{\text {reg }}$ cells ${ }^{98,146}$. Other members of the TNF family, such as 41BB, OX40 or TNFR superfamily member 25 (also known as death receptor 3 (DR3)), can also inhibit the differentiation of induced $\mathrm{T}_{\text {reg }}$ cells ${ }^{147-149}$. These observations suggest that a shared mechanism is involved, perhaps implicating NF-KB, PI3K or MAPK pathways. IFN $\gamma$ produced by T cells following TNFR co-stimulation has also been proposed to inhibit the differentiation of induced $\mathrm{T}_{\text {reg }}$ cells. Alternatively, the increased activation of the PI3K-AKT pathway resulting from TNFR signalling could lead to reduced activation of phosphorylated SMAD3, which transactivates Foxp 3 expression in mouse induced $\mathrm{T}_{\text {reg }}$ cells ${ }^{144}$.

\section{[H2] Overall effects of TNF on $T_{\text {reg }}$ cells}

In summary, TNF has multiple negative and positive effects on $\mathrm{T}_{\text {reg }}$ cell biology, most probably resulting from TNFR2 rather than TNFR1 signalling (Figure 2). The best-characterized of the positive effects of TNF are increased $\mathrm{T}_{\text {reg }}$ cell proliferation and expansion. TNF also seems to promote $T_{\text {reg }}$ cell survival in vitro, although the relevance of this effect in vivo is difficult to evaluate. The TNF-dependent increases in $\mathrm{T}_{\text {reg }}$ cell proliferation and survival are at least partially dependent on RelA and activation of the canonical NF-KB pathway. Involvement of p38 and 
PI3K-AKT pathway activation has also been suggested but requires further investigation.

Finally, weak evidence indicates that TNF increases the stability and suppressive function of $\mathrm{T}_{\text {reg }}$ cells, a phenomenon that might be partially due to TNF signalling synergizing with IL-2 signalling and with phosphorylation of STAT5. Other reports suggest a negative effect of TNF on $\mathrm{T}_{\text {reg }}$ cell biology in vitro. Whether this cytokine truly has a negative effect on $\mathrm{T}_{\text {reg }}$ cell function is questionable. By contrast, TNF seems to increase $T_{\text {reg }}$ cell suppressive function in vivo, at least in some inflammatory contexts. However, the evidence of an inhibitory effect of TNF on differentiation of induced $\mathrm{T}_{\text {reg }}$ cells is fairly solid and might involve the PI3K-AKT pathway (Figure 2).

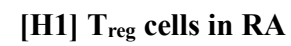

As $T_{\text {reg }}$ cells have an important role in the suppression of autoimmunity, numerous studies have attempted to identify whether these cells have a quantitative or functional defect in patients with autoimmune diseases. Major drawbacks of these studies include the use of sample sizes too small to account for interindividual variability and the absence of a specific marker for human $\mathrm{T}_{\text {reg }}$ cells, which has led to the utilization of different combinations of markers. As a result, the literature is full of conflicting data.

I present here the main findings on $\mathrm{T}_{\text {reg }}$ cell proportion and function in patients with RA. This disease is particularly interesting as $T_{\text {reg }}$ cells can be obtained from both the blood and joints (the target tissue of the disease), which are easily accessible for analysis. Data obtained in other autoimmune diseases are also included where relevant.

\section{[H2] Treg cell proportion}

Contrasting findings have been reported in studies of the proportion of $\mathrm{T}_{\text {reg }}$ cells in the blood of patients with RA receiving conventional immunosuppressive treatment (the effects of TNF inhibitors are discussed below). Among studies that compared patients with RA with healthy control individuals, four described a decreased $\mathrm{T}_{\text {reg }}$ cell proportion ${ }^{75,150-152}$, five found no difference ${ }^{98,126,146,153,154}$ and one found an increased $T_{\text {reg }}$ cell proportion in the patients with $\mathrm{RA}^{155}$.

Most studies that have analyzed both blood and synovial fluid of patients with RA concluded that the proportion of $\mathrm{T}_{\text {reg }}$ cells was higher in synovial fluid than in blood, and remained stable over time in individual patients ${ }^{152,155-157}$. The $\mathrm{T}_{\text {reg }}$ cells isolated from synovial fluid seem to be bona fide $\mathrm{T}_{\text {reg }}$ cells because they exhibit $F O X P 3$ promoter demethylation. Also, the phenotype of these $T_{\text {reg }}$ cells indicates that they have an activated status ${ }^{157}$. The synovial fluid 
of patients with RA contains high amounts of IL-6, TNF and IFN $\gamma$, low levels of IL-17A, IL-10 or IL-13 and does not contain IL-1 ${ }^{126,157}$. Which of these factors is responsible for the increased proportion and activation of synovial $\mathrm{T}_{\text {reg }}$ cells remains unclear. However, IL-6 is not likely to be involved, because this cytokine (which is produced by joint fibroblasts) induces transdifferentiation of $\mathrm{T}_{\text {reg }}$ cells into highly pathogenic $\mathrm{T}_{\mathrm{H}} 17$ cells in a mouse model of autoimmune arthritis, a phenomenon that might also take place in patients with RA ${ }^{158}$. IL- 6 also induced proteasomal degradation of FOXP3 and loss of the suppressive activity of $\mathrm{T}_{\text {reg }}$ cells ${ }^{159,160}$. We do not know much about the effect of IFN $\gamma$ on $\mathrm{T}_{\text {reg }}$ cells. Therefore, the activation and/or expansion of $\mathrm{T}_{\text {reg }}$ cells in the synovial fluid of patients with RA is likely to be caused by high local levels of TNF.

\section{[H2] $T_{\text {reg cell function }}$}

Compared with $\mathrm{T}_{\text {reg }}$ cells obtained from the blood of healthy control individuals, $\mathrm{T}_{\text {reg }}$ cells isolated from the blood of patients with RA were shown to have similar suppressive activity in one study ${ }^{155}$ and decreased suppressive activity in another ${ }^{128}$. In a third study, the capacity of these cells to suppress conventional $\mathrm{T}$ cell proliferation was maintained but their cytokine production was reduced ${ }^{98}$. Contrasting findings have also been reported for the suppressive activity of $\mathrm{T}_{\text {reg }}$ cells isolated from the synovial fluid of patients with RA. Several studies showed that synovial fluid $\mathrm{T}_{\text {reg }}$ cells from patients with RA were as active, or were more active, than blood $\mathrm{T}_{\text {reg }}$ cells from either patients with RA or healthy control individuals in terms of suppression of proliferation or IFN $\gamma$ production ${ }^{152,155-157}$. Another publication reported that synovial fluid $\mathrm{T}_{\text {reg }}$ cells from patients with RA had decreased suppressive activity ${ }^{126}$. Importantly, these studies noted considerable variation between patients, with $\mathrm{T}_{\text {reg }}$ cells from some individuals but not others showing a high level of suppression ${ }^{157}$. This observation might explain the contrasting results and further emphasizes the importance of generating data from at least 7-10 different patients, which was not the case for most of these studies.

Firm conclusions are difficult to draw because the available evidence does not provide a clear picture of whether $T_{\text {reg }}$ cells in the blood of patients with RA have similar proportions and functions to those of healthy control individuals. The situation is a little bit clearer for synovial fluid $\mathrm{T}_{\text {reg }}$ cells, which seem to be present at an increased proportion in patients with RA.

\section{[H2] Effects of TNF inhibitors}


The proportion of $\mathrm{T}_{\text {reg }}$ cells in the blood has been analyzed in many studies of patients with RA 3-6 months (typically 3 months) after initiation of TNF inhibitor treatment. In studies of infliximab-treated patients with RA, the $\mathrm{T}_{\text {reg }}$ cell proportion increased ${ }^{75,98,115,146,151}$ after treatment (Table 4). In studies of patients with RA treated with either adalimumab or etanercept, the $\mathrm{T}_{\text {reg }}$ cell proportion was either increased ${ }^{150,154,161}$ or unchanged ${ }^{153,154,162}$ (Table 4). This $\mathrm{T}_{\text {reg }}$ cell increase was more often observed in responding than in non-responding patients.

Moreover, in studies of infliximab-treated patients with Crohn disease or IBD (Supplementary Table 1), the $\mathrm{T}_{\text {reg }}$ cell proportion was also either unchanged ${ }^{99,163}$ or increased $^{100,115,163-168}$. Some of the studies in patients with IBD or Crohn disease also analyzed the kinetics of this treatment-related increase in $\mathrm{T}_{\text {reg }}$ cell proportion. In a study of patients with Crohn disease, the increase was transient and only occurred after the first injection ${ }^{165}$. In two studies of patients with IBD, the increase occurred 2 weeks after the first injection and was maintained for $\geq 22$ weeks ${ }^{100,166}$, whereas in another study in patients with Crohn disease no increase was detected after 1 week but an increase was detected at week 24 in patients who had low $\mathrm{T}_{\text {reg }}$ cell proportions before treatment ${ }^{99}$ (Supplementary Table 1).

Two studies in patients with uveitis ${ }^{169,170}$ and one in patients with ankylosing spondylitis ${ }^{171}$ showed an increase in the $\mathrm{T}_{\text {reg }}$ cell proportion after TNF inhibitor therapy. However, one study in patients with juvenile idiopathic arthritis observed no difference ${ }^{172}$ and one in patients with sarcoidosis observed a decrease in the $T_{\text {reg }}$ cell proportion ${ }^{173}$ following TNF inhibitor therapy (Table 4).

Some general conclusions can be drawn from these data. Most publications described an increase in the proportion of $\mathrm{T}_{\text {reg }}$ cells in blood after TNF inhibitor therapy. Discrepancies between some studies could be due to the following factors: first, infliximab seems to induce an increase in the $T_{\text {reg }}$ cell proportion more consistently than either adalimumab or etanercept. Second, a $\mathrm{T}_{\text {reg }}$ cell increase seems to be more consistent among patients who responded to TNF inhibitor treatment. The type of concomitant medications might also matter. For instance, although methotrexate monotherapy induces an increase in $\mathrm{T}_{\text {reg }}$ cell proportion ${ }^{150}$, combination therapy with methotrexate and a TNF inhibitor provided an optimal increase in $\mathrm{T}_{\text {reg }}$ cells in vitro $^{174}$. Also, steroid treatment might increase $\mathrm{T}_{\text {reg }}$ cell proportion and function ${ }^{175,176}$. Finally, as discussed above, technical factors related to the way that $\mathrm{T}_{\text {reg }}$ cells were purified might influence the conclusions of these studies. Some activated conventional T cells (which also express CD25) are likely to contaminate the population identified as $T_{\text {reg }}$ cells. Thus, the findings of these studies have to be considered carefully because the level of conventional $\mathrm{T}$ cell contamination could differ between healthy control individuals and patients with rheumatic or autoimmune 
disease, or before and after TNF inhibitor treatment. Use of the CD45RA (naive T cell) or CD45RO (memory T cell) markers, in addition to CD25 or CD127, would help to limit the risk of such contamination ${ }^{134}$.

Several mechanisms by which $\mathrm{T}_{\text {reg }}$ cells might increase after TNF inhibitor treatment are supported by experimental evidence. First, $T_{\text {reg }}$ cells might increase because treatment with TNF blockers such as infliximab favour the differentiation of peripheral $\mathrm{T}_{\text {reg }}$ cells ${ }^{146}$. Second, $\mathrm{T}_{\text {reg }}$ cells might increase because treatment with anti-TNF mAbs such as adalimumab augments the expression of transmembrane TNF on monocytes, which then triggers $\mathrm{T}_{\text {reg }}$ cell expansion via TNFR2 signalling. Thus, anti-TNF mAbs that are intended to inhibit TNF might paradoxically increase its activity ${ }^{84}$. The preferential expansion of activated $\mathrm{T}_{\text {reg }}$ cells rather than resting $\mathrm{T}_{\text {reg }}$ cells in patients receiving anti-TNF mAbs supports this hypothesis ${ }^{100}$. In patients with RA ${ }^{151}$ or $\mathrm{IBD}^{168}, \mathrm{~T}_{\text {reg }}$ cells that are more sensitive to spontaneous apoptosis than are those of healthy control individuals, might be present at an increased proportion in patients treated with TNF inhibitors because they are protected from cell death by this therapy. In patients with IBD, TNF inhibitor therapy blocks $\mathrm{T}_{\text {reg }}$ cell migration to inflamed tissues, which results in increased $\mathrm{T}_{\text {reg }}$ cell levels in blood and decreased levels in the intestinal mucosa ${ }^{166}$. Finally, TNF inhibitor therapy leads to a decrease in inflammatory cytokine levels and pathogenic $\mathrm{T}$ cells while sparing $\mathrm{T}_{\text {reg }}$ cells in patients with Crohn disease ${ }^{161}$ or ankylosing spondylitis ${ }^{165,171}$. Therefore, this treatment might target conventional $\mathrm{T}$ cells in preference to $\mathrm{T}_{\text {reg }}$ cells, thereby explaining the relative increase in the $\mathrm{T}_{\text {reg }}$ cell proportion within the population of $\mathrm{CD}^{+} \mathrm{T}$ cells. As the increased proportion of blood $\mathrm{T}_{\text {reg }}$ cells following TNF inhibitor treatment is an in vivo phenomenon that occurs over a long time period, determining which of the above-described mechanisms is most relevant remains a challenge.

\section{[H3] Suppressive function.}

Treatment with $\mathrm{mAb}$ TNF inhibitors affects not only the $\mathrm{T}_{\text {reg }}$ cell proportion but also their suppressive function. Early work showed that $\mathrm{T}_{\text {reg }}$ cells from patients with RA obtained before the initiation of TNF inhibitor therapy had a poor capacity to suppress cytokine production by conventional $\mathrm{T}$ cells, and that the suppressive activity of these $\mathrm{T}_{\text {reg }}$ cells was restored following anti-TNF treatment ${ }^{98}$. These functional $T_{\text {reg }}$ cells resulted from either the generation of new peripheral $\mathrm{T}_{\text {reg }}$ cells following infliximab treatment ${ }^{146}$ or from the expansion of differentiated $\mathrm{T}_{\text {reg }}$ cells following adalimumab treatment ${ }^{84}$. These restored $\mathrm{T}_{\text {reg }}$ cells were even able to suppress pathogenic $\mathrm{T}_{\mathrm{H}} 17$ cells, unlike the $\mathrm{T}_{\text {reg }}$ cells of healthy control individuals ${ }^{154}$. Dysfunction of $\mathrm{T}_{\text {reg }}$ cells obtained from the blood or synovial fluid of patients with RA and restoration of their 
suppressive function after TNF inhibitor treatment (infliximab) were also confirmed in two other studies ${ }^{126,128}$. Restoration of functional blood $\mathrm{T}_{\text {reg }}$ cells after TNF inhibitor treatment has also been described in patients with IBD $^{164}$.

TNF inhibitors based on mAbs seem to act, at least in part, by restoring the functional $\mathrm{T}_{\text {reg }}$ cell compartment. By contrast, etanercept is likely to act by suppressing conventional $\mathrm{T}$ cells and/or rendering them sensitive to the suppressive effects of $\mathrm{T}_{\text {reg }}$ cells ${ }^{172,177}$. In another study, $\mathrm{T}_{\text {reg }}$ cells obtained from patients with Crohn disease were shown to be functional even before initiation of infliximab treatment ${ }^{178}$. However, the $\mathrm{T}_{\text {reg }}$ cell purification strategy used in this paper meant that activated conventional $\mathrm{T}$ cells might have contaminated the population of $\mathrm{T}_{\mathrm{reg}}$ cells, thereby resulting in an inaccurate measurement of the suppressive activity of genuine $T_{\text {reg }}$ cells. Therefore, the conclusions of this report have to be interpreted with caution.

In summary, the beneficial effects of TNF inhibitor therapies could be due to either restoration of fully functional $\mathrm{T}_{\text {reg }}$ cells or to an increased susceptibility of conventional $\mathrm{T}$ cells to the suppressive effects of $\mathrm{T}_{\text {reg }}$ cells.

\section{[H3] $T_{\text {reg }}$ cell biomarkers of response.}

The development of biomarkers to identify the $20-30 \%$ of patients with RA or IBD who will not respond to TNF inhibitor therapy is highly desirable, and some $\mathrm{T}_{\text {reg }}$ cell-related biomarkers are potential candidates. In some studies, an increase in the $\mathrm{T}_{\text {reg }}$ cell proportion after TNF inhibitor treatment was observed only in patients who responded to this therapy (Table 4). Thus, the $\mathrm{T}_{\text {reg }}$ cell proportion before TNF inhibitor treatment has been proposed as a predictive biomarker to predict treatment response. However, patients with IBD who respond to TNF inhibitors could have $T_{\text {reg }}$ cell proportions before therapy that are either higher ${ }^{99,100}$ or lower ${ }^{178}$ than those of nonresponding patients. Moreover, in patients with ankylosing spondylitis ${ }^{171,174}$ or RA ${ }^{171,174}$, the $\mathrm{T}_{\text {reg }}$ cell proportion before TNF inhibitor therapy was not predictive of treatment efficacy.

As discussed above, a possible mechanism for the observed increase of $\mathrm{T}_{\text {reg }}$ cells upon $\mathrm{mAb}$ TNF inhibitor treatment is binding of the mAb to transmembrane TNF on myeloid cells, leading first to its increased expression and then to a boost in $\mathrm{T}_{\text {reg }}$ cell numbers mediated by TNFR2 signalling ${ }^{84}$. As the expression of transmembrane TNF on monocytes can be readily assessed by flow cytometry, the capacity of adalimumab to provoke an increase in $\mathrm{T}_{\text {reg }}$ cell numbers in a 3-day culture has been used to identify which patients with RA would respond to this treatment ${ }^{174}$ 
In summary, pretreatment $\mathrm{T}_{\text {reg }}$ cell proportion does not seem to be a reliable biomarker of response to anti-TNF therapies. The expression of transmembrane TNF on myeloid cells as a biomarker of treatment response deserves to be confirmed in other studies.

\section{[H1] Next-generation drugs targeting TNF}

The putative mechanisms underlying non-response and paradoxical autoimmunity to TNF inhibitor treatment could be explained by the regulatory aspect of TNF. Blocking TNF is associated with an increased risk of impairing the activity of some suppressor cells, including $\mathrm{T}_{\text {reg }}$ cells, or increasing the activation of autoreactive $\mathrm{T}$ cells. The overall effect of these treatments is likely to depend on the specific autoimmune disease present, its stage and severity, and on genetic and environmental factors unique to each patient. At the time of treatment, if TNF has a dominant inflammatory and pathogenic role, TNF inhibitors will be beneficial. By contrast, if TNF has a dominant regulatory and protective role, TNF inhibitors will be detrimental.

Given that most of the pro-inflammatory properties of TNF are due to TNFR1 signalling induced by soluble TNF and most of the regulatory properties of are due to TNFR2 signalling induced by transmembrane TNF, the next generation of TNF inhibitors might preferentially target TNFR1 or TNFR2 $2^{14,25,82,86,88,179,180}$. Two types of TNFR-specific agents have been proposed: mAbs and so-called TNF muteins, which are forms of this cytokine harbouring mutations in the receptor-interacting domains ${ }^{181-183}$.

\section{[H2] Selective TNFR1 antagonists}

The capacity of TNFR1 antagonists to block the pro-inflammatory interaction of TNF with TNFR1 has been investigated in mouse models of autoimmune diseases.

Both mAbs and TNF muteins have been developed that have potent TNFR1 antagonist activity and a strong therapeutic effect in mouse models of autoimmune diseases (Table 5). For example, the mAb DMS5540 was as effective as etanercept in the treatment of collagen-induced arthritis. In addition, the effects of DMS5540 on immune cells were superior to those of etanercept, as DMS5540 induced $\mathrm{T}_{\text {reg }}$ cell activation and reduced the activation of conventional $\mathrm{T}$ cells, a phenomenon not observed with etanercept ${ }^{184}$. Several anti-TNFR1 mAbs (namely atrosab, trivalent nanobody TNFR1 silencer (TROS) and HM1097) were able to suppress EAE $^{185-187}$. Finally, the muteins XPro1595 and R1antTNF had therapeutic effects in arthritis or EAE; when these agents were compared with etanercept, they sometimes demonstrated improved efficacy ${ }^{188-192}$. 


\section{[H2] TNFR2 agonists}

As TNFR2 signalling stimulates the expansion of $\mathrm{T}_{\text {reg }}$ cells, TNFR2 agonists such as the $\mathrm{mAbs}$ MR2-1 and another unnamed version are interesting candidates for improving $T_{\text {reg }}$ cell therapy in autoimmune diseases (Table 5). When added to human $\mathrm{T}_{\text {reg }}$ cell cultures, these $\mathrm{mAbs}$ promote the expansion and improve the stability and purity of $\mathrm{T}_{\text {reg }}$ cells over time ${ }^{111,118}$.

Two additional TNF muteins with human TNFR2 agonist activity (TNF07 and TNC$\mathrm{scTNF}_{\mathrm{R} 2}$ ) have been generated ${ }^{116,193}$ and TNF07 has been shown to promote $\mathrm{T}_{\text {reg }}$ cell activation in vitro. In the future, mAbs or TNF muteins with TNFR2 agonist activity might be used to improve cell culture methods used to generate $T_{\text {reg }}$ cell preparations for use in cell therapy. This notion is supported by mouse studies showing that adding TNF or a TNFR2 agonist to $\mathrm{T}_{\text {reg }}$ cell cultures increased the capacity of these cells to suppress colitis ${ }^{103,130}$ or $\mathrm{GvHD}^{103,130}$ after their reintroduction in vivo ${ }^{103,130}$.

The capacity of TNFR2 agonists to stimulate $\mathrm{T}_{\text {reg }}$ cells in vivo has been tested in mouse models. Treatment with either of two TNF muteins with TNFR2 agonist activity (STAR2 and EHD2-sc-mTNF 2$)^{194,195}$ induced in vivo $T_{\text {reg }}$ cell activation and expansion ${ }^{117,120}$ that was associated with prevention or amelioration of arthritis ${ }^{119,121}, \mathrm{EAE}^{132}$ or $\mathrm{GvHD}^{117}$. These agents also protected the central nervous system of treated animals from inflammation and neuronal injury induced by chronic nerve constriction or drug treatment, respectively ${ }^{195,196}$.

Whereas classical immunosuppressive drugs aim to suppress autoimmunity by neutralizing pathogenic cells, an alternative approach is based on increasing the expansion or suppressive capacity of $\mathrm{T}_{\text {reg }}$ cells. A prototype of this new class of drugs is IL-2 ${ }^{197}$. Our group showed that administration of low-dose IL-2 boosts the proliferation of $\mathrm{T}_{\text {reg }}$ cells and induces remission of type 1 diabetes mellitus in non-obese diabetic mice ${ }^{198,199}$. Low-dose IL-2 is now being investigated as a treatment for other autoimmune diseases in multiple clinical trials. One study has investigated this treatment in 14 different autoimmune diseases, including RA and ankylosing spondylitis (NCT01988506). TNFR2 agonists are another type of drug that are able to boost the number or function of $\mathrm{T}_{\text {reg }}$ cells. No clinical trial has so far investigated the use of TNFR2 agonists to treat an autoimmune disease. However, bacillus Calmette-Guérin (BCG) vaccine can induce TNF release without secondary effects, thereby providing an indirect way to trigger TNFR2 signalling. BCG vaccine has been tested for efficacy in type 1 diabetes (NCT00607230 and NCT02081326).

\section{[H1] Conclusions}

TNF has a long and fascinating yet chaotic history. This cytokine was discovered in the mid- 
1970s and named for its effect as a tumour cell killer. Major milestones in its history include its cloning in the mid-1980s, the discovery that TNF binds to two receptors, that its signalling transduction is highly complex (and still remains to be fully explored), and that it has multiple effects at steady state.

TNF is now known to be one of the most important inflammatory cytokines. Although TNF is critical for beneficial immune responses, the realization that TNF is also harmful in many autoimmune diseases led to the great success of TNF inhibitors and ultimately to the flowering of research into other biological therapies. The regulatory role of this cytokine is also important to consider. Here again, the mechanisms underlying the immunosuppressive activity of TNF are complex. However, one of its main features seems to involve the expression of transmembrane TNF on myeloid or T cells, which interacts with TNFR2 on $\mathrm{T}_{\text {reg }}$ cells to boost their proliferation and maybe also their stability and suppressive function.

The inflammatory and regulatory roles of TNF are both essential to take into account in the design of future generations of TNF inhibitors. Preclinical studies have shown that selective antagonists of TNFR1 inhibit the inflammatory action of TNF whereas selective agonists of TNFR2 boost $\mathrm{T}_{\text {reg }}$ cell numbers and potentially also improve their function. Therefore, TNFR1 antagonists and TNFR2 agonists could be beneficial in future treatments of several diseases with an autoimmune component.. In the future, biotechnology and pharmaceutical companies are expected to work hand in hand with academic laboratories towards the successful translation of these fascinating observations into the clinic.

\section{Acknowledgements}

The author thanks current and past members of his laboratory for their hard work and fruitful and passionate exchanges on the effects of TNF on $\mathrm{T}_{\text {reg }}$ cells. His research work is supported by Agence Nationale de la Recherche (grants ANR-15-CE15-0015-03 and ANR-17-CE15-0030-01) and Fondation pour la Recherche Médicale (équipe FRM).

\section{Competing interests}

B.S. declares that he received consultancy fees from HiFiBio Therapeutics regarding the applications of TNFR2 agonists and antagonists in cancer and autoimmunity.

\section{Peer review information}

Nature Reviews Rheumatology thanks [Referee\#1 name], [Referee\#2 name] and the other, anonymous, reviewer(s) for their contribution to the peer review of this work. 


\section{Supplementary information}

Supplementary information is available for this paper at https://doi.org/10.1038/s415XX-XXX-

XXXX-X

\section{Key points}

- Tumour necrosis factor (TNF) is a major inflammatory cytokine that has deleterious effects in several rheumatic and autoimmune diseases, as attested by the success of TNF inhibitor therapy.

- Some patients do not respond to TNF inhibitors and others develop paradoxical autoimmune exacerbations that can be explained by the immunoregulatory role of TNF.

- The pro-inflammatory and anti-inflammatory properties of TNF are largely segregated by the capacity of this cytokine to bind to TNF receptor 1 (TNFR1) and TNF receptor 2 (TNFR2), respectively.

- The anti-inflammatory effects of TNF are explained by its capacity to increase the proliferation, stability and suppressive function of $\mathrm{FOXP}^{+}$regulatory $\mathrm{T}$ cells via TNFR2 signalling.

- Antagonists of TNFR1 and agonists of TNFR2 constitute a new generation of drugs that might be more effective and have fewer adverse effects than classical TNF inhibitors. 
Table 1. Clinically approved TNF inhibitors in the USA and Europe

\begin{tabular}{|c|c|c|c|}
\hline Drug & Molecule & Biosimilars & $\begin{array}{l}\text { Approved rheumatic } \\
\text { disease indications }{ }^{\mathrm{a}}\end{array}$ \\
\hline Etanercept & $\begin{array}{l}\text { Human TNFR2-IgG1-Fc } \\
\text { fusion protein }\end{array}$ & Benpali, Erelzi, Nepexto & $\begin{array}{l}\text { RA, JIA, psoriatic arthritis, } \\
\text { plaque psoriasis, AS }\end{array}$ \\
\hline Infliximab & $\begin{array}{l}\text { Humanized chimeric anti- } \\
\text { TNF IgG } 1 / \kappa \mathrm{mAb}\end{array}$ & $\begin{array}{l}\text { Remsima, Inflectra, Flixabi, Ixifi, } \\
\text { Zessly, Avsola }\end{array}$ & $\begin{array}{l}\text { RA, psoriatic arthritis, } \\
\text { plaque psoriasis, AS }\end{array}$ \\
\hline Adalimumab & $\begin{array}{l}\text { Fully human anti-TNF } \\
\text { IgG1/ } \kappa \mathrm{mAb}\end{array}$ & $\begin{array}{l}\text { Exemptia, Adfrar, Amjevita, Cyltezo, } \\
\text { Amgevita, Solymbic, Imraldi, Cyltezo, } \\
\text { Halimatoz, Hefiya, Hyrimoz, Hulio, } \\
\text { Idacio, Kromeya, Hadlima, Abrilada, } \\
\text { Amsparity }\end{array}$ & $\begin{array}{l}\text { RA, JIA, psoriatic arthritis, } \\
\text { plaque psoriasis, AS, } \\
\text { hidradenitis suppurativa, } \\
\text { non-infectious uveitis }\end{array}$ \\
\hline Certolizumab pegol & $\begin{array}{l}\text { PEGylated human Fab } \\
\text { fragment of anti-TNF mAb }\end{array}$ & NA & $\begin{array}{l}\text { RA (Europe only), } \\
\text { psoriatic arthritis }\end{array}$ \\
\hline Golimumab & $\begin{array}{l}\text { Fully human anti-TNF } \\
\text { IgG1/ } \mathrm{kAb}\end{array}$ & NA & RA, psoriatic arthritis, AS \\
\hline
\end{tabular}

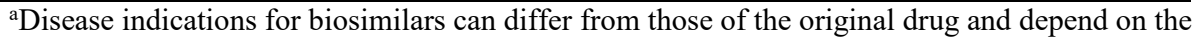
countries where they are registered. AS, ankylosing spondylitis; JIA, juvenile idiopathic arthritis;
Commenté [JM1]: Caroline: Check against table 1 in the published paper below for overlap:

https://www.mdpi.com/2073-4468/4/1/48/html?

This table might need to be adjusted to avoid overlap (or else might need permissions).

(see handover sheet for one idea of alt layout) mAb, monoclonal antibody; NA, not applicable; RA, rheumatoid arthritis. 
Table 2. Pathogenic and protective roles of TNFR1 and TNFR2 in models of rheumatic and autoimmune diseases

\begin{tabular}{|l|l|l|l|l|l|}
\hline Mouse model & $\begin{array}{l}\text { TNFR1 } \\
\text { knockout }\end{array}$ & TNFR2 knockout & $\begin{array}{l}\text { TNFR1 } \\
\text { antagonist }\end{array}$ & TNFR2 agonist & Refs \\
\hline $\begin{array}{l}\text { Collagen-induced } \\
\text { arthritis }\end{array}$ & Attenuated & Exacerbated & Attenuated & Attenuated & $200,201,184,119,121$ \\
\hline $\begin{array}{l}\text { Antigen-induced } \\
\text { arthritis }\end{array}$ & ND & Exacerbated & ND & ND & 201 \\
\hline DTHA & ND & Exacerbated & ND & ND & 115 \\
\hline $\begin{array}{l}\text { Arthritis in TNF- } \\
\text { transgenic mice }\end{array}$ & Attenuated & Exacerbated & ND & ND & 202 \\
\hline EAE & Attenuated & Exacerbated & Attenuated & Attenuated & $\begin{array}{l}28,187,203- \\
205,28,187,191,203,204, \\
206,207,208,132\end{array}$ \\
\hline
\end{tabular}

DTHA, delayed-type hypersensitivity arthritis; EAE, experimental autoimmune encephalomyelitis; ND, not determined. 
Table 3. Effect of TNF on $\mathrm{T}_{\text {reg }}$ cell function in vitro.

\begin{tabular}{|c|c|c|c|c|c|c|}
\hline$T_{\text {reg }}$ cell population & Culture condition(s) & $n$ & $\begin{array}{l}\text { TNF } \\
\text { added }\end{array}$ & Assay type & $\begin{array}{l}\text { Effect of TNF } \\
\text { on Treg cell } \\
\text { suppression }\end{array}$ & Refs \\
\hline Human $\mathrm{CD} 4^{+} \mathrm{CD} 25^{\text {hi }}$ & $\begin{array}{l}\text { Soluble anti-CD3 and } \\
\text { anti-CD28 mAbs }\end{array}$ & 6 & $\begin{array}{l}\text { Before or } \\
\text { during }\end{array}$ & $\begin{array}{l}\text { Cytokine } \\
\text { FACS }\end{array}$ & No change & 98 \\
\hline Human $\mathrm{CD} 4^{+} \mathrm{CD} 25^{\mathrm{hi}}$ & Coated anti-CD3 mAbs & 6 & Before & $\begin{array}{l}\text { Proliferation } \\
{ }^{3} \mathrm{H}\end{array}$ & Decreased & 128 \\
\hline Human $\mathrm{CD} 4^{+} \mathrm{CD} 25^{+}$ & HBV e-antigen & 7 & None & $\begin{array}{l}\text { Proliferation } \\
{ }^{3} \mathrm{H}\end{array}$ & Decreased & 127 \\
\hline Human $\mathrm{CD} 4^{+} \mathrm{CD} 25^{+}$ & Coated anti-CD3 mAbs & NR & During & $\begin{array}{l}\text { Proliferation } \\
\text { FACS, } \\
\text { cytokine } \\
\text { ELISA }\end{array}$ & Decreased & 129 \\
\hline Human $\mathrm{CD} 4^{+} \mathrm{CD} 25^{\text {hi }}$ & Coated anti-CD3 mAbs & 3 & $\begin{array}{l}\text { Before or } \\
\text { during }\end{array}$ & $\begin{array}{l}\text { Proliferation } \\
\text { FACS }\end{array}$ & Decreased & 122 \\
\hline $\begin{array}{l}\text { Human } \\
\mathrm{CD} 4^{+} \mathrm{CD} 25^{\text {hi }} \mathrm{CD} 127^{\text {low }}\end{array}$ & $\begin{array}{l}\text { Coated anti-CD3 and } \\
\text { anti-CD28 mAbs }\end{array}$ & $5 ?$ & Before & $\begin{array}{l}\text { Proliferation } \\
\text { FACS }\end{array}$ & Decreased & 126 \\
\hline $\begin{array}{l}\text { Human } \\
\mathrm{CD}^{+} \mathrm{CD} 25^{\text {hi }} \mathrm{CD} 127^{\text {low }} \\
\mathrm{CD}^{2} 5 \mathrm{RA}^{-}\end{array}$ & $\begin{array}{l}\text { Coated anti-CD3 and } \\
\text { anti-CD28 mAbs; APC } \\
\text { and soluble anti-CD3 } \\
\text { mAbs; APC and coated } \\
\text { anti-CD3 mAbs }\end{array}$ & 28 & $\begin{array}{l}\text { Before or } \\
\text { during }\end{array}$ & $\begin{array}{l}\text { Proliferation } \\
\text { FACS }\end{array}$ & $\begin{array}{l}\text { No change or } \\
\text { increased }\end{array}$ & 133 \\
\hline Mouse $\mathrm{CD} 4^{+} \mathrm{CD} 25^{+}$ & $\begin{array}{l}\text { APC and soluble anti- } \\
\text { CD3 mAbs }\end{array}$ & 6 & $\begin{array}{l}\text { Before or } \\
\text { during }\end{array}$ & $\begin{array}{l}\text { Proliferation } \\
\text { FACS }\end{array}$ & $\begin{array}{l}\text { No change or } \\
\text { increased }\end{array}$ & 22 \\
\hline Mouse $\mathrm{CD} 4^{+} \mathrm{CD} 25^{+}$ & $\begin{array}{l}\text { APC and soluble anti- } \\
\text { CD3 mAbs }\end{array}$ & 3 & Before & $\begin{array}{l}\text { Proliferation } \\
\text { FACS }\end{array}$ & Increased & 107 \\
\hline
\end{tabular}

APC, antigen presenting cells; ELISA, enzyme-linked immunosorbent assay; FACS,

fluorescence-activated cell sorting; $n$, number of healthy individuals; NR, not reported; TNF, tumour necrosis factor. 
817 Table $4 . \mathrm{T}_{\text {reg }}$ cell proportions in blood before and after TNF inhibitor therapy

\begin{tabular}{|c|c|c|c|c|c|c|}
\hline \multirow[b]{2}{*}{$\begin{array}{l}\text { Study } \\
\text { population }\end{array}$} & \multirow[b]{2}{*}{$\begin{array}{l}\text { TNF inhibitor } \\
\text { (concomitant } \\
\text { medications) }\end{array}$} & \multirow[b]{2}{*}{$\begin{array}{l}\text { Sampling } \\
\text { time points }\end{array}$} & \multicolumn{3}{|c|}{$\mathbf{T}_{\text {reg }}$ cells } & \multirow[b]{2}{*}{ Refs } \\
\hline & & & Cell population & $\begin{array}{l}\text { Pre- } \\
\text { treatment } \\
\text { (proportion) }\end{array}$ & $\begin{array}{l}\text { Post-treatment } \\
\text { (proportion) }\end{array}$ & \\
\hline $\begin{array}{l}27 \text { patients with } \\
\text { RA; } 8 \text { healthy } \\
\text { controls }\end{array}$ & $\begin{array}{l}\text { Infliximab (NSAIDs, } \\
\text { methotrexate) }\end{array}$ & $\begin{array}{l}\text { Baseline, } 1.5 \\
\text { and } 3.0 \\
\text { months }\end{array}$ & $\mathrm{CD} 4^{+} \mathrm{CD} 25^{\mathrm{hi}}$ & Same & $\begin{array}{l}\text { Increased from } \\
\text { baseline; increased in } \\
\text { responders vs } \\
\text { nonresponders }\end{array}$ & 98 \\
\hline $\begin{array}{l}17 \text { patients with } \\
\text { RA; } 15 \text { healthy } \\
\text { controls }\end{array}$ & $\begin{array}{l}\text { Infliximab (NSAIDs, } \\
\text { methotrexate) }\end{array}$ & $\begin{array}{l}\text { Baseline and } \\
3.0 \text { months }\end{array}$ & $\mathrm{CD} 4^{+} \mathrm{CD} 25^{\mathrm{hi}}$ & Decreased $^{\mathrm{c}}$ & $\begin{array}{l}\text { Increased from } \\
\text { baseline }\end{array}$ & 151 \\
\hline $\begin{array}{l}31 \text { patients with } \\
\text { RA; } 20 \text { healthy } \\
\text { controls }\end{array}$ & $\begin{array}{l}\text { Infliximab (NSAIDs, } \\
\text { methotrexate) }\end{array}$ & $\begin{array}{l}\text { Baseline and } \\
4.0-6.0 \\
\text { months }\end{array}$ & $\mathrm{CD}^{+} \mathrm{FOXP}^{+}$ & Same & Increased from baseline & 146 \\
\hline $\begin{array}{l}40 \text { patients with } \\
\text { RA; } 10 \text { healthy } \\
\text { controls }\end{array}$ & $\begin{array}{l}\text { Infliximab } \\
\text { (methotrexate, } \\
\text { salazopyrin, } \\
\text { hydroxychloroquine, } \\
\text { steroids) }\end{array}$ & NR & $\begin{array}{l}\mathrm{CD} 4^{+} \mathrm{CD} 25^{+} \mathrm{FOX} \\
\mathrm{P}^{+}\end{array}$ & Decreased & $\begin{array}{l}\text { Increased from baseline } \\
\text { and in responders vs } \\
\text { nonresponders }\end{array}$ & 75 \\
\hline $\begin{array}{l}10 \text { patients with } \\
\text { RA; } 10 \text { healthy } \\
\text { controls }\end{array}$ & $\begin{array}{l}\text { Adalimumab } \\
\text { (NSAIDs } \\
\text { methotrexate, } \\
\text { steroids) }\end{array}$ & $\begin{array}{l}\text { Baseline and } \\
3.0 \text { months }\end{array}$ & $\mathrm{CD} 4^{+} \mathrm{CD} 25^{\mathrm{hi}}$ & Same & $\begin{array}{l}\text { No change from } \\
\text { baseline }\end{array}$ & 153 \\
\hline $\begin{array}{l}50 \text { patients with } \\
\text { RA; } 15 \text { healthy } \\
\text { controls }\end{array}$ & $\begin{array}{l}\text { Adalimumab or } \\
\text { etanercept (NR) }\end{array}$ & NR & $\mathrm{CD}^{+} \mathrm{FOXP}^{+}$ & Same & $\begin{array}{l}\text { Increased from } \\
\text { baseline; increased in } \\
\text { responders vs } \\
\text { nonresponders to } \\
\text { adalimumab; no change } \\
\text { from baseline with } \\
\text { etanercept }\end{array}$ & 154 \\
\hline $\begin{array}{l}48 \text { patients with } \\
\text { RA }\end{array}$ & $\begin{array}{l}\text { Adalimumab or } \\
\text { etanercept } \\
\text { (methotrexate, } \\
\text { leflunomide) }\end{array}$ & $\begin{array}{l}\text { Baseline, } 1.5 \\
\text { and } 3.0 \\
\text { months }\end{array}$ & $\begin{array}{l}\mathrm{CD} 4^{+} \mathrm{FOXP}^{+}, \\
\mathrm{CD} 25^{\mathrm{h}} 127^{\text {low }}\end{array}$ & ND & $\begin{array}{l}\text { No change from } \\
\text { baseline, no difference } \\
\text { between responders and } \\
\text { nonresponders }\end{array}$ & 162 \\
\hline $\begin{array}{l}20 \text { patients with } \\
\text { RA; } 10 \text { healthy } \\
\text { controls }\end{array}$ & $\begin{array}{l}\text { Etanercept } \\
\text { (methotrexate) }\end{array}$ & $\begin{array}{l}\text { Baseline and } \\
3.0 \text { months }\end{array}$ & $\begin{array}{l}\mathrm{CD} 4^{+} \mathrm{CD} 25^{\text {hiFOX }} \\
\mathrm{P}^{+}\end{array}$ & Decreased & Increased from baseline & 150 \\
\hline $\begin{array}{l}33 \text { patients with } \\
\text { RA }\end{array}$ & $\begin{array}{l}\text { Etanercept } \\
\text { (methotrexate) }\end{array}$ & $\begin{array}{l}\text { Baseline, } 3.0 \\
\text { and } 6.0 \\
\text { months }\end{array}$ & $\begin{array}{l}\mathrm{CD} 4^{+} \mathrm{CD} 25^{+} \mathrm{FOX} \\
\mathrm{P}^{+}\end{array}$ & ND & Increased from baseline & 161 \\
\hline $\begin{array}{l}16 \text { patients with } \\
\text { RA }\end{array}$ & $\begin{array}{l}\text { Infliximab or } \\
\text { etanercept }^{\mathrm{d}}(\mathrm{NR})\end{array}$ & $\begin{array}{l}\text { Baseline and } \\
3.0 \text { months }\end{array}$ & $\begin{array}{l}\mathrm{CD}^{+} \mathrm{CD} 25^{+} 127^{\mathrm{lo}} \\
{ }^{\mathrm{w}} \mathrm{FOXP}^{+}\end{array}$ & ND & Increased from baseline & 115 \\
\hline $\begin{array}{l}7 \text { patients with } \\
\text { JIA }\end{array}$ & $\begin{array}{l}\text { Etanercept (NSAIDs, } \\
\text { methotrexate) }\end{array}$ & $\begin{array}{l}\text { Baseline and } \\
1.0-5.0 \\
\text { months }\end{array}$ & $\mathrm{CD}^{+} \mathrm{FOXP}^{+}$ & ND & $\begin{array}{l}\text { No change from } \\
\text { baseline }\end{array}$ & 172 \\
\hline $\begin{array}{l}222 \text { patients } \\
\text { with AS; } 68 \\
\text { healthy controls }\end{array}$ & $\begin{array}{l}\text { Infliximab or } \\
\text { etanercept (NSAIDs) }\end{array}$ & $\begin{array}{l}\text { Baseline and } \\
6.0 \text { months }\end{array}$ & $\begin{array}{l}\mathrm{CD} 4^{+} \mathrm{CD} 25^{\text {hiFOX }} \\
\mathrm{P}^{+}\end{array}$ & Decreased & $\begin{array}{l}\text { Increased from } \\
\text { baseline; increased in } \\
\text { responders versus } \\
\text { nonresponders }\end{array}$ & 171 \\
\hline $\begin{array}{l}46 \text { patients with } \\
\text { sarcoidosis; } 26 \\
\text { healthy controls }\end{array}$ & Infliximab (NR) & $\begin{array}{l}\text { Baseline, } 3.5 \\
\text { and } 6.0 \\
\text { months }\end{array}$ & $\mathrm{CD} 4^{+} \mathrm{CD} 25^{\mathrm{hi}}$ & Increased & $\begin{array}{l}\text { Decreased from } \\
\text { baseline }\end{array}$ & 173 \\
\hline $\begin{array}{l}12 \text { patients with } \\
\text { uveitis }\end{array}$ & Adalimumab (NR) & $\begin{array}{l}\text { Baseline, } 1.0 \\
\text { and } 6.0 \\
\text { months }\end{array}$ & $\begin{array}{l}\mathrm{CD} 4^{+} \mathrm{CD} 25^{\text {hi }} 127^{\text {lo }} \\
{ }^{\text {FOXP }} 3^{+}\end{array}$ & ND & Increased from baseline & 169 \\
\hline $\begin{array}{l}16 \text { patients with } \\
\text { uveitis; } 15 \\
\text { healthy controls }\end{array}$ & Infliximab (NR) & $\begin{array}{l}\text { Baseline, } 4.0- \\
27.0 \text { months }\end{array}$ & $\mathrm{CD}^{+} \mathrm{FOXP}^{+}$ & Same & $\begin{array}{l}\text { Increased from } \\
\text { baseline }^{\mathrm{e}}\end{array}$ & 170 \\
\hline
\end{tabular}

$818{ }^{\mathrm{a}}$ Baseline (before initiation of TNF inhibitor treatment). ${ }^{\mathrm{b}}$ In patients versus controls. ${ }^{\mathrm{c}} \mathrm{Absolute}$

819 number. ${ }^{\mathrm{d}}$ Three patients also received golimumab, adalimumab or certolizumab. ${ }^{\text {eVersus patients }}$ 

treated only with ciclosporine or colchicine. AS, ankylosing spondylitis; JIA, juvenile idiopathic arthritis; ND, not determined; NR, not reported; NSAID, nonsteroidal anti-inflammatory drug. 
823 Table 5. Therapeutic effects of drugs targeting TNFRs in autoimmune disease models

\begin{tabular}{|c|c|c|c|}
\hline Agent & Structure & Therapeutic efficacy & Refs \\
\hline & Antagonists of TNFR1 & & \\
\hline DMS5540 & Bispecific anti-TNFR1 and anti-albumin $\mathrm{mAb}$ & Arthritis (CIA) & 184 \\
\hline ASTROSAB & $\begin{array}{l}\text { Humanized anti-TNFR1 IgG1 mAb, mutated in } \\
\text { the Fc fragment to abrogate complement and } \\
\text { immune complex activation }\end{array}$ & EAE & 185 \\
\hline TROS & $\begin{array}{l}\text { Trivalent nanobody comprising two } \mathrm{mAb} \\
\text { domains binding to TNFR1 and one mAb domain } \\
\text { binding to albumin }\end{array}$ & EAE & 186 \\
\hline HM1097 & Hamster IgG & EAE & 187 \\
\hline XPro1595 & $\begin{array}{l}\text { Dominant-negative PEGylated TNF muteins that } \\
\text { interact with soluble TNF to form inactive } \\
\text { heterotrimers, which have low binding and } \\
\text { signalling activity }\end{array}$ & Arthritis (CIA) and EAE & $188,190,192$ \\
\hline \multirow[t]{2}{*}{ RlantTNF } & $\begin{array}{l}\text { PEGylated TNF mutein that binds specifically to } \\
\text { TNFR1 without signalling activity }\end{array}$ & Arthritis (CIA) and EAE & 189,191 \\
\hline & Agonists of TNFR2 & & \\
\hline MR2-1 & Mouse $\mathrm{mAb}$ against human TNFR2 & $\begin{array}{l}\text { Increased expansion and stability of } \mathrm{T}_{\text {reg }} \\
\text { cells; not tested in vivo }\end{array}$ & 57,118 \\
\hline Unnamed & Mouse mAb against human TNFR2 & $\begin{array}{l}\text { Increased expansion and stability of } \mathrm{T}_{\mathrm{reg}} \\
\text { cells; not tested in vivo }\end{array}$ & 111 \\
\hline TNF07 & Human TNF mutein trimer & $\begin{array}{l}\text { Increased expansion of } \mathrm{T}_{\text {reg }} \text { cells; not } \\
\text { tested in vivo }\end{array}$ & 116 \\
\hline $\begin{array}{l}\text { TNC- } \\
\text { scTNF}_{\text {R2 }}\end{array}$ & Human TNF mutein trimer & Not tested in vitro or vivo & 193 \\
\hline STAR2 & Mouse TNF mutein nanomer & $\begin{array}{l}\text { Increased expansion, survival and } \\
\text { function of } T_{\text {reg cells; }} \text { effective in CIA, } \\
\text { EAE and GvHD }\end{array}$ & $\begin{array}{l}121,103,117,12 \\
0,132\end{array}$ \\
\hline $\begin{array}{l}\text { EHD2-sc- } \\
\text { mTNF}_{R 2}\end{array}$ & Mouse TNF mutein hexamer & $\begin{array}{l}\text { Increased expansion of } \mathrm{T}_{\text {reg }} \text { cells; } \\
\text { effective in EAE and CIA }\end{array}$ & 119,208 \\
\hline
\end{tabular}

CIA, collagen-induced arthritis; EAE, experimental autoimmune encephalomyelitis; GvHD, 
Figure 1. The proinflammatory and anti-inflammatory activities of TNF are driven by effects on innate and adaptive immunity. Tumour necrosis factor (TNF) is a major proinflammatory cytokine (top panel) that activates both innate (left side) and adaptive (right side) immunity. TNF promotes recruitment of leukocytes, favours the production of other proinflammatory cytokines, activates neutrophils and participates in co-stimulation of conventional T cells. TNF also has regulatory activities (bottom panel) such as inhibition of haematopoiesis, increased glucocorticoid production, activation of suppressive cells (such as mesenchymal stem cells (MSC) and myeloid-derived suppressor cells (MDSC)) or altering the function of dendritic cells (DCs) and macrophages. TNF also regulates immunity by promoting IL-10-producing B cells, inducing T cell apoptosis, altering T cell receptor (TCR) signalling, inhibiting $\mathrm{T}_{\mathrm{H}} 17$ cell differentiation and boosting numbers and function of regulatory $\mathrm{T}\left(\mathrm{T}_{\text {reg }}\right)$ cells. APC, antigen-presenting cell; FLS, fibroblast-like synoviocyte; HSC, haematopoietic stem cell.

Figure 2. The overall effects of TNF on regulatory $\mathbf{T}$ cells. Most of the effects of tumour necrosis factor $(\mathrm{TNF})$ on regulatory $\mathrm{T}\left(\mathrm{T}_{\mathrm{reg}}\right)$ cells are due to induction of TNF receptor 1 (TNFR2) signalling, which is probably preferentially mediated by transmembrane TNF rather than soluble TNF. Signal transduction downstream of TNFR2 that does not involve kinase activity involves TNF receptor-associated factor (TRAF) adaptor proteins. Multiple downstream signalling pathways lead to positive (left) and negative (right) effects on $\mathrm{T}_{\text {reg }}$ cell biology. TNFR2 signalling strongly induces $\mathrm{T}_{\text {reg }}$ cell proliferation and has a moderate survival-promoting effect on $\mathrm{T}_{\text {reg }}$ cells; both of these effects depend on RelA and probably also on the activation of p38, AKT and mTORC1 by phosphorylation (p). Weak evidence indicates that TNF also promotes the stability and suppressive function of $\mathrm{T}_{\text {reg }}$ cells, perhaps via TNF-induced protein 3 (TNFAIP3)and signal transducer and activator of transcription 5 (STAT5) signalling pathways. In addition to these positive effects of TNF, the negative effects of this cytokine are clear in relation to the inhibition of induced $\mathrm{T}_{\text {reg }}$ cell differentiation (which involves phosphoinositide 3kinase (PI3K) and/or phosphorylated RAC $\alpha$ serine/threonine-protein kinase (AKT) pathway activation). Weak evidence suggests that TNF induces $\mathrm{T}_{\text {reg }}$ cell dysfunction, perhaps via a mechanism involving deleted in breast cancer 1 (DBC1), microRNA 34a (miR-34a) and serine/threonine-protein phosphatase PP1. Arrow thickness and box shading intensity is proportional to the importance of the effect or the likelihood that a given molecule is involved in the pathway. 


\section{References}

1. Feldmann, M. Translating molecular insights in autoimmunity into effective therapy. Annu Rev Immunol 27, 1-27 (2009).

2. Monaco, C., Nanchahal, J., Taylor, P. \& Feldmann, M. Anti-TNF therapy: past, present and future. Int Immunol 27, 55-62 (2015).

3. Keffer, J. et al. Transgenic mice expressing human tumour necrosis factor: a predictive genetic model of arthritis. EMBO J 10, 4025-31 (1991).

4. Silva-Fernandez, L. \& Hyrich, K. Rheumatoid arthritis: When TNF inhibitors fail in RA-weighing up the options. Nat Rev Rheumatol 10, 262-4 (2014).

5. Roda, G., Jharap, B., Neeraj, N. \& Colombel, J.F. Loss of Response to Anti-TNFs: Definition, Epidemiology, and Management. Clin Transl Gastroenterol 7, e135 (2016).

6. Esposito, M. et al. Survival rate of antitumour necrosis factor-alpha treatments for psoriasis in routine dermatological practice: a multicentre observational study. $\mathrm{Br} J$ Dermatol 169, 666-72 (2013).

7. Ramos-Casals, M., Brito-Zeron, P., Soto, M.J., Cuadrado, M.J. \& Khamashta, M.A. Autoimmune diseases induced by TNF-targeted therapies. Best Pract Res Clin Rheumatol 22, 847-61 (2008).

8. Ramos-Casals, M. et al. Autoimmune diseases induced by biological agents: a doubleedged sword? Autoimmun Rev 9, 188-93 (2010).

9. Brenner, D., Blaser, H. \& Mak, T.W. Regulation of tumour necrosis factor signalling: live or let die. Nat Rev Immunol 15, 362-74 (2015).

10. Conrad, C. et al. TNF blockade induces a dysregulated type 1 interferon response without autoimmunity in paradoxical psoriasis. Nat Commun 9, 25 (2018).

11. van Oosten, B.W. et al. Increased MRI activity and immune activation in two multiple sclerosis patients treated with the monoclonal anti-tumor necrosis factor antibody cA2. Neurology 47, 1531-4 (1996).

12. Study-group. TNF neutralization in MS: results of a randomized, placebo-controlled multicenter study. The Lenercept Multiple Sclerosis Study Group and The University of British Columbia MS/MRI Analysis Group. Neurology 53, 457-65 (1999).

13. Aggarwal, B.B., Gupta, S.C. \& Kim, J.H. Historical perspectives on tumor necrosis factor and its superfamily: 25 years later, a golden journey. Blood 119, 651-65 (2012).

14. Kalliolias, G.D. \& Ivashkiv, L.B. TNF biology, pathogenic mechanisms and emerging therapeutic strategies. Nat Rev Rheumatol 12, 49-62 (2016).

15. Atretkhany, K.N., Gogoleva, V.S., Drutskaya, M.S. \& Nedospasov, S.A. Distinct modes of TNF signaling through its two receptors in health and disease. J Leukoc Biol (2020).

16. Salomon, B.L. et al. Tumor Necrosis Factor alpha and Regulatory T Cells in Oncoimmunology. Front Immunol 9, 444 (2018).

17. Davignon, J.L. et al. Modulation of T-cell responses by anti-tumor necrosis factor treatments in rheumatoid arthritis: a review. Arthritis Res Ther 20, 229 (2018).

18. Horiuchi, T., Mitoma, H., Harashima, S., Tsukamoto, H. \& Shimoda, T. Transmembrane TNF-a: structure, function and interaction with anti-TNF agents. Rheumatology (Oxford) 49, 1215-1228 (2010).

19. Lee, W.H., Seo, D., Lim, S.G. \& Suk, K. Reverse Signaling of Tumor Necrosis Factor Superfamily Proteins in Macrophages and Microglia: Superfamily Portrait in the Neuroimmune Interface. Front Immunol 10, 262 (2019).

20. Qu, Y., Zhao, G. \& H., L. Forward and Reverse Signaling Mediated by Transmembrane Tumor Necrosis Factor-Alpha and TNF Receptor 2: Potential Roles in an immunosuppressive Tumor Microenvironment. . Front Immunol 8, 1675 (2017).

21. Aggarwal, B.B. Signalling pathways of the TNF superfamily: a double-edged sword. Nat Rev Immunol 3, 745-56 (2003). 
22. Chen, X., Baumel, M., Mannel, D.N., Howard, O.M. \& Oppenheim, J.J. Interaction of TNF with TNF receptor type 2 promotes expansion and function of mouse CD4+CD25+ T regulatory cells. J Immunol 179, 154-61 (2007).

23. Ware, C.F. Network communications: lymphotoxins, LIGHT, and TNF. Annu Rev Immunol 23, 787-819 (2005).

24. Yang, S., Wang, J., Brand, D.D. \& Zheng, S.G. Role of TNF-TNF Receptor 2 Signal in Regulatory T Cells and Its Therapeutic Implications. Front Immunol 9, 784 (2018).

25. Faustman, D. \& Davis, M. TNF receptor 2 pathway: drug target for autoimmune diseases. Nat Rev Drug Discov 9, $482-93$ (2010).

26. Gregory, A.P. et al. TNF receptor 1 genetic risk mirrors outcome of anti-TNF therapy in multiple sclerosis. Nature 488, 508-511 (2012).

27. Park, H., Bourla, A.B., Kastner, D.L., Colbert, R.A. \& Siegel, R.M. Lighting the fires within: the cell biology of autoinflammatory diseases. Nat Rev Immunol 12, 570-80 (2012).

28. Yang, S. et al. Differential roles of TNFalpha-TNFR1 and TNFalpha-TNFR2 in the differentiation and function of CD4(+)Foxp3(+) induced Treg cells in vitro and in vivo periphery in autoimmune diseases. Cell Death Dis 10, 27 (2019).

29. Rampart, M., De Smet, W., Fiers, W. \& Herman, A.G. Inflammatory properties of recombinant tumor necrosis factor in rabbit skin in vivo. $J$ Exp Med 169, 2227-32 (1989).

30. Venkatesh, D. et al. Endothelial TNF receptor 2 induces IRF1 transcription factordependent interferon-beta autocrine signaling to promote monocyte recruitment. Immunity 38, 1025-37 (2013).

31. Duprez, L. et al. RIP kinase-dependent necrosis drives lethal systemic inflammatory response syndrome. Immunity 35, 908-18 (2011).

32. Ding, $X$. et al. TNF receptor 1 mediates dendritic cell maturation and CD8 T cell response through two distinct mechanisms. J Immunol 187, 1184-91 (2011).

33. Menges, M. et al. Repetitive injections of dendritic cells matured with tumor necrosis factor alpha induce antigen-specific protection of mice from autoimmunity. $J \operatorname{Exp} M e d$ 195, 15-21 (2002).

34. Noti, M., Corazza, N., Mueller, C., Berger, B. \& Brunner, T. TNF suppresses acute intestinal inflammation by inducing local glucocorticoid synthesis. $J$ Exp Med 207, 1057 66 (2010).

35. Wang, W. et al. Enhanced human hematopoietic stem and progenitor cell engraftment by blocking donor T cell-mediated TNFalpha signaling. Sci Transl Med 9 (2017).

36. Ghannam, S., Pene, J., Moquet-Torcy, G., Jorgensen, C. \& Yssel, H. Mesenchymal stem cells inhibit human Th17 cell differentiation and function and induce a T regulatory cell phenotype. J Immunol 185, 302-12 (2010).

37. Sayegh, S. et al. Rheumatoid Synovial Fluids Regulate the Immunomodulatory Potential of Adipose-Derived Mesenchymal Stem Cells Through a TNF/NF-kappaB-Dependent Mechanism. Front Immunol 10, 1482 (2019).

38. Raveney, B.J., Copland, D.A., Dick, A.D. \& Nicholson, L.B. TNFR1-dependent regulation of myeloid cell function in experimental autoimmune uveoretinitis. J Immunol 183, 2321-9 (2009).

39. Zhao, X. et al. TNF signaling drives myeloid-derived suppressor cell accumulation. $J$ Clin Invest 122, 4094-104 (2012).

40. Chavez-Galan, L. et al. Transmembrane Tumor Necrosis Factor Controls MyeloidDerived Suppressor Cell Activity via TNF Receptor 2 and Protects from Excessive Inflammation during BCG-Induced Pleurisy. Front Immunol 8, 999 (2017).

41. $\mathrm{Hu}, \mathrm{X}$. et al. Transmembrane TNF-alpha promotes suppressive activities of myeloidderived suppressor cells via TNFR2. J Immunol 192, 1320-31 (2014). 
42. Sade-Feldman, M. et al. Tumor necrosis factor-alpha blocks differentiation and enhances suppressive activity of immature myeloid cells during chronic inflammation. Immunity 38, 541-54 (2013).

43. Bachus, H. et al. Impaired Tumor-Necrosis-Factor-alpha-driven Dendritic Cell Activation Limits Lipopolysaccharide-Induced Protection from Allergic Inflammation in Infants. Immunity 50, 225-240 e4 (2019).

44. Alzabin, S. et al. Incomplete response of inflammatory arthritis to TNF $\alpha$ blockade is associated with the Th17 pathway. Ann Rheum Dis 71, 1741-1748 (2012).

45. Mayordomo, A.C. et al. IL-12/23p40 overproduction by dendritic cells leads to an increased Th1 and Th17 polarization in a model of Yersinia enterocolitica-induced reactive arthritis in TNFRp55-/- mice. PLoS One 13, e0193573 (2018).

46. Notley, C.A. et al. Blockade of tumor necrosis factor in collagen-induced arthritis reveals a novel immunoregulatory pathway for Th1 and Th17 cells. J Exp Med 205, 2491-7 (2008).

47. Park, S.H., Park-Min, K.H., Chen, J., Hu, X. \& Ivashkiv, L.B. Tumor necrosis factor induces GSK3 kinase-mediated cross-tolerance to endotoxin in macrophages. Nat Immunol 12, 607-15 (2011).

48. Zakharova, M. \& Ziegler, H.K. Paradoxical anti-inflammatory actions of TNF-alpha: inhibition of IL-12 and IL-23 via TNF receptor 1 in macrophages and dendritic cells. $J$ Immunol 175, 5024-33 (2005).

49. Kusnadi, A. et al. The Cytokine TNF Promotes Transcription Factor SREBP Activity and Binding to Inflammatory Genes to Activate Macrophages and Limit Tissue Repair. Immunity 51, 241-257 e9 (2019).

50. Park, S.H. et al. Type I interferons and the cytokine TNF cooperatively reprogram the macrophage epigenome to promote inflammatory activation. Nat Immunol 18, 1104-1116 (2017).

51. Tartaglia, L.A. et al. Stimulation of human T-cell proliferation by specific activation of the 75-kDa tumor necrosis factor receptor. J Immunol 151, 4637-41 (1993).

52. Kim, E.Y. \& Teh, H.S. Critical role of TNF receptor type-2 (p75) as a costimulator for IL-2 induction and T cell survival: a functional link to CD28. J Immunol 173, 4500-9 (2004).

53. Kim, E.Y., Priatel, J.J., Teh, S.J. \& Teh, H.S. TNF receptor type 2 (p75) functions as a costimulator for antigen-driven T cell responses in vivo. J Immunol 176, 1026-35 (2006).

54. Calzascia, T. et al. TNF-alpha is critical for antitumor but not antiviral T cell immunity in mice. $J$ Clin Invest 117, 3833-45 (2007).

55. Chen, X. et al. TNFR2 expression by CD4 effector T cells is required to induce fullfledged experimental colitis. Sci Rep 6, 32834 (2016).

56. Soloviova, K., Puliaiev, M., Haas, M. \& Via, C.S. In vivo maturation of allo-specific CD8 CTL and prevention of lupus-like graft-versus-host disease is critically dependent on T cell signaling through the TNF 75 receptor but not the TNF p55 receptor. $J$ Immunol 190, 4562-72 (2013).

57. de Kivit, S. et al. Stable human regulatory T cells switch to glycolysis following TNF receptor 2 costimulation. Nat Metab 2, 1046-1061 (2020).

58. Schioppa, T. et al. B regulatory cells and the tumor-promoting actions of TNF-alpha during squamous carcinogenesis. Proc Natl Acad Sci US A 108, 10662-7 (2011).

59. Cope, A.P. et al. Chronic tumor necrosis factor alters $T$ cell responses by attenuating $T$ cell receptor signaling. J Exp Med 185, 1573-84 (1997).

60. Aspalter, R.M., Wolf, H.M. \& Eibl, M.M. Chronic TNF-alpha exposure impairs TCRsignaling via TNF-RII but not TNF-RI. Cell Immunol 237, 55-67 (2005). 
61. Beyer, M. et al. Tumor-necrosis factor impairs CD4(+) T cell-mediated immunological control in chronic viral infection. Nat Immunol 17, 593-603 (2016).

62. Qin, H.Y., Chaturvedi, P. \& Singh, B. In vivo apoptosis of diabetogenic T cells in NOD mice by IFN-gamma/TNF-alpha. Int Immunol 16, 1723-32 (2004).

63. Naude, P.J., den Boer, J.A., Luiten, P.G. \& Eisel, U.L. Tumor necrosis factor receptor cross-talk. FEBS J 278, 888-98 (2011).

64. Lin, R.H., Hwang, Y.W., Yang, B.C. \& Lin, C.S. TNF receptor-2-triggered apoptosis is associated with the down-regulation of Bcl-xL on activated T cells and can be prevented by CD28 costimulation. J Immunol 158, 598-603 (1997).

65. Ban, L. et al. Selective death of autoreactive T cells in human diabetes by TNF or TNF receptor 2 agonism. Proc Natl Acad Sci U S A 105, 13644-9 (2008).

66. Bhattacharyya, S. et al. Tumor-induced oxidative stress perturbs nuclear factor-kappaB activity-augmenting tumor necrosis factor-alpha-mediated T-cell death: protection by curcumin. Cancer Res 67, 362-70 (2007).

67. Kim, E.Y., Teh, S.J., Yang, J., Chow, M.T. \& Teh, H.S. TNFR2-deficient memory CD8 $\mathrm{T}$ cells provide superior protection against tumor cell growth. J Immunol 183, 6051-7 (2009).

68. Luckey, U. et al. T cell killing by tolerogenic dendritic cells protects mice from allergy. $J$ Clin Invest 121, 3860-71 (2011).

69. Miller, P.G., Bonn, M.B. \& McKarns, S.C. Transmembrane TNF-TNFR2 Impairs Th17 Differentiation by Promoting Il2 Expression. J Immunol 195, 2633-47 (2015).

70. Urbano, P.C.M. et al. TNF-alpha-induced protein 3 (TNFAIP3)/A20 acts as a master switch in TNF-alpha blockade-driven IL-17A expression. J Allergy Clin Immunol 142, 517-529 (2018).

71. Urbano, P.C.M. et al. TNFalpha-Signaling Modulates the Kinase Activity of Human Effector Treg and Regulates IL-17A Expression. Front Immunol 10, 3047 (2019).

72. Elicabe, R.J. et al. Lack of TNFR p55 results in heightened expression of IFN-gamma and IL-17 during the development of reactive arthritis. J Immunol 185, 4485-95 (2010).

73. Ma, H.L. et al. Tumor necrosis factor alpha blockade exacerbates murine psoriasis-like disease by enhancing Th17 function and decreasing expansion of Treg cells. Arthritis Rheum 62, 430-40 (2010).

74. Hull, D.N. et al. Anti-tumour necrosis factor treatment increases circulating T helper type 17 cells similarly in different types of inflammatory arthritis. Clin Exp Immunol 181, 401-6 (2015).

75. Talotta, R. et al. Paradoxical Expansion of Th1 and Th17 Lymphocytes in Rheumatoid Arthritis Following Infliximab Treatment: a Possible Explanation for a Lack of Clinical Response. J Clin Immunol 35, 550-7 (2015).

76. Kruglov, A.A., Lampropoulou, V., Fillatreau, S. \& Nedospasov, S.A. Pathogenic and protective functions of TNF in neuroinflammation are defined by its expression in T lymphocytes and myeloid cells. J Immunol 187, 5660-5670 (2011).

77. Kruglov, A. et al. Contrasting contributions of TNF from distinct cellular sources in arthritis. Ann Rheum Dis 79, 1453-1459 (2020).

78. Wolf, Y. et al. Autonomous TNF is critical for in vivo monocyte survival in steady state and inflammation. $J$ Exp Med 214, 905-917 (2017).

79. Mukai, Y. et al. Solution of the structure of the TNF-TNFR2 complex. Sci Signal 3, ra83 (2010).

80. Chan, F.K. The pre-ligand binding assembly domain: a potential target of inhibition of tumour necrosis factor receptor function Ann Rheum Dis 59 Suppl 1, i50-53 (2000).

81. Croft, M. \& Siegel, R.M. Beyond TNF: TNF superfamily cytokines as targets for the treatment of rheumatic diseases. Nat Rev Rheumatol 13, 217-233 (2017). 
82. Van Hauwermeiren, F., Vandenbroucke, R.E. \& Libert, C. Treatment of TNF mediated diseases by selective inhibition of soluble TNF or TNFR1. Cytokine Growth Factor Rev 22, 311-9 (2011).

83. Alexopoulou, L. et al. Transmembrane TNF protects mutant mice against intracellular bacterial infections, chronic inflammation and autoimmunity. Eur J Immunol 36, 27682780 (2006).

84. Nguyen, D.X. \& Ehrenstein, M.R. Anti-TNF drives regulatory T cell expansion by paradoxically promoting membrane TNF-TNF-RII binding in rheumatoid arthritis. $J$ Exp Med 213, 1241-53 (2016).

85. Grell, M. et al. The transmembrane form of tumor necrosis factor is the prime activating ligand of the $80 \mathrm{kDa}$ tumor necrosis factor receptor Cell 83, 793-802 (1995).

86. Medler, J. \& Wajant, H. Tumor necrosis factor receptor-2 (TNFR2): an overview of an emerging drug target. Expert Opin Ther Targets 23, 295-307 (2019).

87. So, T. \& Croft, M. Regulation of PI-3-Kinase and Akt Signaling in T Lymphocytes and Other Cells by TNFR Family Molecules. Front Immunol 4, 139 (2013).

88. Wajant, H. \& Beilhack, A. Targeting Regulatory T Cells by Addressing Tumor Necrosis Factor and Its Receptors in Allogeneic Hematopoietic Cell Transplantation and Cancer. Front Immunol 10, 2040 (2019).

89. Twu, Y.C., Gold, M.R. \& Teh, H.S. TNFR1 delivers pro-survival signals that are required for limiting TNFR2-dependent activation-induced cell death (AICD) in CD8+ T cells. Eur J Immunol 41, 335-44 (2011).

90. Catrina, A.C. et al. Evidence that anti-tumor necrosis factor therapy with both etanercept and infliximab induces apoptosis in macrophages, but not lymphocytes, in rheumatoid arthritis joints: extended report. Arthritis Rheum 52, 61-72 (2005).

91. Mitoma, H. et al. Mechanisms for cytotocxic effects of anti-tumor necrosis factors agents on transmembrane tumor necrosis factor a-expressing cells. Arthritis Rheum 58, 124812(è (2008).

92. Tada, Y. et al. Collagen-induced arthritis in TNF receptor-1-deficient mice: TNF receptor-2 can modulate arthritis in the absence of TNF receptor-1. Clinical Immunol 99, 325-333 (2001).

93. Lee, L.F. et al. The role of TNF-alpha in the pathogenesis of type 1 diabetes in the nonobese diabetic mouse: analysis of dendritic cell maturation. Proc Natl Acad Sci U S A 102, 15995-6000 (2005).

94. McDevitt, H., Munson, S., Ettinger, R. \& Wu, A. Multiple roles for tumor necrosis factor-alpha and lymphotoxin alpha/beta in immunity and autoimmunity. Arthritis Res 4 Suppl 3, S141-52 (2002).

95. Green, E.A. \& Flavell, R.A. The temporal importance of TNFalpha expression in the development of diabetes. Immunity 12, 459-69 (2000).

96. Sakaguchi, S., Yamaguchi, T., Nomura, T. \& Ono, M. Regulatory T cells and immune tolerance. Cell 133, 775-87 (2008).

97. Buckner, J.H. Mechanisms of impaired regulation by CD4(+)CD25(+)FOXP3(+) regulatory T cells in human autoimmune diseases. Nat Rev Immunol 10, $849-59$ (2010).

98. Ehrenstein, M.R. et al. Compromised function of regulatory T cells in rheumatoid arthritis and reversal by anti-TNFalpha therapy. $J$ Exp Med 200, 277-85 (2004).

99. Dige, A. et al. Adalimumab treatment in Crohn's disease does not induce early changes in regulatory T cells. Scand J Gastroenterol 46, 1206-14 (2011).

100. Li, Z. et al. Restoration of Foxp3+ Regulatory T-cell Subsets and Foxp3- Type 1 Regulatory-like T Cells in Inflammatory Bowel Diseases During Anti-tumor Necrosis Factor Therapy. Inflamm Bowel Dis 21, 2418-28 (2015). 
101. Bluestone, J.A. \& Tang, Q. Treg cells-the next frontier of cell therapy. Science 362, 154155 (2018).

102. Zemmour, D. et al. Single-cell gene expression reveals a landscape of regulatory $\mathrm{T}$ cell phenotypes shaped by the TCR. Nat Immunol 19, 291-301 (2018).

103. Lubrano di Ricco, M. et al. Tumor necrosis factor receptor family costimulation increases regulatory T-cell activation and function via NF-kappaB. Eur J Immunol (2020).

104. Vasanthakumar, A. et al. The TNF Receptor Superfamily-NF-kappaB Axis Is Critical to Maintain Effector Regulatory T Cells in Lymphoid and Non-lymphoid Tissues. Cell Rep 20, 2906-2920 (2017).

105. Chen, X. et al. Co-expression of TNFR2 and CD25 identifies more of the functional CD4(+)FoxP3(+) regulatory T cells in human peripheral blood. Eur J Immunol 40, 1099$1106(2010)$.

106. Chen, X. et al. Cutting edge: expression of TNFR2 defines a maximally suppressive subset of mouse CD4+CD25+FoxP3+ T regulatory cells: applicability to tumorinfiltrating T regulatory cells. J Immunol 180, 6467-71 (2008).

107. Hamano, R., Huang, J., Yoshimura, T., Oppenheim, J.J. \& Chen, X. TNF optimally activatives regulatory $\mathrm{T}$ cells by inducing TNF receptor superfamily members TNFR2, 41BB and OX40. Eur J Immunol 41, 2010-20 (2011).

108. Grinberg-Bleyer, Y. et al. Pathogenic T cells have a paradoxical protective effect in murine autoimmune diabetes by boosting Tregs. J Clin Invest 120, 4558-68 (2010).

109. Baeyens, A. et al. Effector T Cells Boost Regulatory T Cell Expansion by IL-2, TNF, OX40, and Plasmacytoid Dendritic Cells Depending on the Immune Context. J Immunol 194, 999-1010 (2015).

110. Zhou, Q., Hu, Y., Howard, O.M., Oppenheim, J.J. \& Chen, X. In vitro generated Th17 cells support the expansion and phenotypic stability of CD4(+)Foxp3(+) regulatory $\mathrm{T}$ cells in vivo. Cytokine 65, 56-64 (2014).

111. Okubo, Y., Mera, T., Wang, L. \& Faustman, D.L. Homogeneous expansion of human Tregulatory cells via tumor necrosis factor receptor 2. Sci Rep 3, 3153 (2013).

112. Urbano, P.C.M., Koenen, H., Joosten, I. \& He, X. An Autocrine TNFalpha-Tumor Necrosis Factor Receptor 2 Loop Promotes Epigenetic Effects Inducing Human Treg Stability In Vitro. Front Immunol 9, 573 (2018).

113. Chen, $\mathrm{X}$. et al. TNFR2 is critical for the stabilization of the CD4+Foxp3+ regulatory $\mathrm{T}$. cell phenotype in the inflammatory environment. J Immunol 190, 1076-84 (2013).

114. Housley, W.J. et al. Natural but not inducible regulatory T cells require TNF-alpha signaling for in vivo function. J Immunol 186, 6779-87 (2011).

115. Santinon, F. et al. Involvement of Tumor Necrosis Factor Receptor Type II in FoxP3 Stability and as a Marker of Treg Cells Specifically Expanded by Anti-Tumor Necrosis Factor Treatments in Rheumatoid Arthritis. Arthritis Rheumatol 72, 576-587 (2020).

116. Ban, L. et al. Strategic internal covalent cross-linking of TNF produces a stable TNF trimer with improved TNFR2 signaling. Mol Cell Ther 3, 7 (2015).

117. Chopra, M. et al. Exogenous TNFR2 activation protects from acute GvHD via host T reg cell expansion. $J$ Exp Med 213, 1881-900 (2016).

118. He, X. et al. A TNFR2-Agonist Facilitates High Purity Expansion of Human Low Purity Treg Cells. PLoS One 11, e0156311 (2016).

119. Fischer, R. et al. Selective Activation of Tumor Necrosis Factor Receptor II Induces Antiinflammatory Responses and Alleviates Experimental Arthritis. Arthritis Rheumatol 70, $722-735$ (2018).

120. Joedicke, J.J. et al. Activated CD8+ T cells induce expansion of Vbeta5+ regulatory T cells via TNFR2 signaling. J Immunol 193, 2952-60 (2014). 
121. Lamontain, V. et al. Stimulation of TNF receptor type 2 expands regulatory T cells and ameliorates established collagen-induced arthritis in mice. Cell Mol Immunol 16, 65-74 (2019).

122. Nagar, M. et al. TNF activates a NF-kappaB-regulated cellular program in human CD45RA- regulatory T cells that modulates their suppressive function. J Immunol 184, 3570-81 (2010).

123. Wang, J. et al. TNFR2 ligation in human T regulatory cells enhances IL2-induced cell proliferation through the non-canonical NF-kappaB pathway. Sci Rep 8, 12079 (2018).

124. Bittner, S. \& Ehrenschwender, M. Multifaceted death receptor 3 signaling-promoting survival and triggering death. FEBS Lett 591, 2543-2555 (2017).

125. He, T. et al. The p38 MAPK Inhibitor SB203580 Abrogates Tumor Necrosis FactorInduced Proliferative Expansion of Mouse CD4(+)Foxp3(+) Regulatory T Cells. Front Immunol 9, 1556 (2018).

126. Nie, H. et al. Phosphorylation of FOXP3 controls regulatory T cell function and is inhibited by TNF-alpha in rheumatoid arthritis. Nat Med 19, 322-8 (2013).

127. Stoop, J.N. et al. Tumor necrosis factor alpha inhibits the suppressive effect of regulatory $\mathrm{T}$ cells on the hepatitis B virus-specific immune response. Hepatology 46, 699-705 (2007).

128. Valencia, X. et al. TNF downmodulates the function of human CD4+CD25hi Tregulatory cells. Blood 108, 253-61 (2006).

129. Zanin-Zhorov, A. et al. Protein kinase C-theta mediates negative feedback on regulatory T cell function. Science 328, 372-6 (2010).

130. Pierini, A. et al. TNF-alpha priming enhances CD4+FoxP3+ regulatory T-cell suppressive function in murine GVHD prevention and treatment. Blood 128, 866-71 (2016).

131. Leclerc, M. et al. Control of GVHD by regulatory T cells depends on TNF produced by T cells and TNFR2 expressed by regulatory T cells. Blood 128, 1651-9 (2016).

132. Ronin, E. et al. Tissue-restricted control of established central nervous system autoimmunity by TNF receptor 2-expressing

Treg cells. Proc Natl Acad Sci U S A 118, e2014043118 (2021).

133. Zaragoza, B. et al. Suppressive activity of human regulatory T cells is maintained in the presence of TNF. Nat Med 22, 16-7 (2016).

134. Miyara, M. et al. Functional delineation and differentiation dynamics of human CD4+ T cells expressing the FoxP3 transcription factor. Immunity 30, 899-911 (2009).

135. Chen, X. et al. Expression of costimulatory TNFR2 induces resistance of CD4+FoxP3conventional T cells to suppression by CD4+FoxP3+ regulatory T cells. J Immunol $\mathbf{1 8 5}$, 174-82 (2010).

136. Yamaguchi, T., Wing, J.B. \& Sakaguchi, S. Two modes of immune suppression by Foxp3(+) regulatory T cells under inflammatory or non-inflammatory conditions. Semin Immunol 23, 424-30 (2011).

137. Chaudhry, A. \& Rudensky, A.Y. Control of inflammation by integration of environmental cues by regulatory T cells. J Clin Invest 123, 939-44 (2013).

138. Williams, L.M. \& Rudensky, A.Y. Maintenance of the Foxp3-dependent developmental program in mature regulatory $\mathrm{T}$ cells requires continued expression of Foxp3. Nat Immunol 8, 277-84 (2007).

139. Chinen, T. et al. An essential role for the IL-2 receptor in T reg cell function Nat Immunol 17, 1322-1333 (2016).

140. Feng, Y. et al. Control of the inheritance of regulatory $\mathrm{T}$ cell identity by a cis element in the Foxp3 locus Cell 158, 749-763 (2014). 
141. Gao, Y. et al. Inflammation negatively regulates FOXP3 and regulatory T-cell function via DBC1. Proc Natl Acad Sci U S A 112, E3246-54 (2015).

142. Xie, M. et al. NF-kappaB-driven miR-34a impairs Treg/Th17 balance via targeting Foxp3. J Autoimmun 102, 96-113 (2019).

143. Molinero, L.L., Miller, M.L., Evaristo, C. \& Alegre, M.L. High TCR stimuli prevent induced regulatory $\mathrm{T}$ cell differentiation in a NF-kappaB-dependent manner. J Immunol 186, 4609-17 (2011).

144. Zhang, Q. et al. TNF-alpha impairs differentiation and function of TGF-beta-induced Treg cells in autoimmune diseases through Akt and Smad3 signaling pathway. J Mol Cell Biol 5, 85-98 (2013).

145. Mahmud, S.A. et al. Costimulation via the tumor-necrosis factor receptor superfamily couples TCR signal strength to the thymic differentiation of regulatory T cells. Nat Immunol 15, 473-81 (2014).

146. Nadkarni, S., Mauri, C. \& Ehrenstein, M.R. Anti-TNF-alpha therapy induces a distinct regulatory $\mathrm{T}$ cell population in patients with rheumatoid arthritis via TGF-beta. $J$ Exp Med 204, 33-9 (2007).

147. So, T. \& Croft, M. Cutting edge: OX40 inhibits TGF-beta- and antigen-driven conversion of naive CD4 T cells into CD25+Foxp3+ T cells. J Immunol 179, 1427-30 (2007).

148. Madireddi, S. et al. SA-4-1BBL costimulation inhibits conversion of conventional CD4+ T cells into CD4+ FoxP3+ T regulatory cells by production of IFN- $\gamma$ PLoS One 7, e42459 (2012).

149. Khan, S.Q. et al. Cloning, expression, and functional characterization of TL1A-Ig $J$ Immunol 190, 1540-1550 (2013).

150. Lina, C., Conghua, W., Nan, L. \& Ping, Z. Combined treatment of etanercept and MTX reverses Th1/Th2, Th17/Treg imbalance in patients with rheumatoid arthritis. J Clin Immunol 31, 596-605 (2011).

151. Toubi, E. et al. Increased spontaneous apoptosis of CD4+CD25+ T cells in patients with active rheumatoid arthritis is reduced by infliximab Ann N Y Acad Sci 1051, 506-514 (2005).

152. Cao, D., van Vollenhoven, R., Klareskog, L., Trollmo, C. \& Malmstrom, V. CD25brightCD4+ regulatory T cells are enriched in inflamed joints of patients with chronic rheumatic disease. Arthritis Res Ther 6, R335-46 (2004).

153. Dombrecht, E.J. et al. Influence of anti-tumor necrosis factor therapy (Adalimumab) on regulatory $\mathrm{T}$ cells and dendritic cells in rheumatoid arthritis. Clin Exp Rheumatol 24, 317 (2006).

154. McGovern, J.L. et al. Th17 cells are restrained by Treg cells via the inhibition of interleukin-6 in patients with rheumatoid arthritis responding to anti-tumor necrosis factor antibody therapy. Arthritis Rheum 64, 3129-38 (2012).

155. van Amelsfort, J.M., Jacobs, K.M., Bijlsma, J.W., Lafeber, F.P. \& Taams, L.S. $\mathrm{CD} 4(+) \mathrm{CD} 25(+)$ regulatory $\mathrm{T}$ cells in rheumatoid arthritis: differences in the presence, phenotype, and function between peripheral blood and synovial fluid. Arthritis Rheum 50, 2775-85 (2004).

156. Cao, D. et al. Isolation and functional characterization of regulatory CD25brightCD4+ T cells from the target organ of patients with rheumatoid arthritis. Eur J Immunol 33, 21523 (2003).

157. Herrath, J. et al. The inflammatory milieu in the rheumatic joint reduces regulatory T-cell function. Eur J Immunol 41, 2279-90 (2011).

158. Komatsu, N. et al. Pathogenic conversion of Foxp3+ T cells into TH17 cells in autoimmune arthritis. Nat Med 20, 62-8 (2014). 
159. Chen, Z. et al. The ubiquitin ligase Stub1 negatively modulates regulatory T cell suppressive activity by promoting degradation of the transcription factor Foxp3. Immunity 39, 272-85 (2013).

160. van Loosdregt, J. et al. Stabilization of the transcription factor Foxp 3 by the deubiquitinase USP7 increases Treg-cell-suppressive capacity. Immunity 39, 259-71 (2013).

161. Huang, Z. et al. Anti-TNF-alpha therapy improves Treg and suppresses Teff in patients with rheumatoid arthritis. Cell Immunol 279, 25-9 (2012).

162. Blache, C. et al. Number and phenotype of rheumatoid arthritis patients' CD4+CD25hi regulatory $\mathrm{T}$ cells are not affected by adalimumab or etanercept. Rheumatology (Oxford) 50, 1814-22 (2011).

163. Hvas, C.L. et al. Discrete changes in circulating regulatory T cells during infliximab treatment of Crohn's disease. Autoimmunity 43, 325-33 (2010).

164. Boschetti, G. et al. Therapy with anti-TNFalpha antibody enhances number and function of Foxp3 $(+)$ regulatory T cells in inflammatory bowel diseases. Inflamm Bowel Dis $\mathbf{1 7}$ 160-70 (2011).

165. Kato, K. et al. Infliximab therapy impacts the peripheral immune system of immunomodulator and corticosteroid naive patients with Crohn's disease. Gut Liver 5, 37-45 (2011).

166. Li, Z. et al. Reciprocal changes of Foxp3 expression in blood and intestinal mucosa in IBD patients responding to infliximab. Inflamm Bowel Dis 16, 1299-310 (2010).

167. Ricciardelli, I., Lindley, K.J., Londei, M. \& Quaratino, S. Anti tumour necrosis-alpha therapy increases the number of FOXP3 regulatory T cells in children affected by Crohn's disease. Immunology 125, 178-83 (2008).

168. Veltkamp, C. et al. Apoptosis of regulatory T lymphocytes is increased in chronic inflammatory bowel disease and reversed by anti-TNFalpha treatment. Gut 60, 1345-53 (2011).

169. Calleja, S. et al. Adalimumab specifically induces CD3(+) CD4(+) CD25(high) Foxp3(+) CD127(-) T-regulatory cells and decreases vascular endothelial growth factor plasma levels in refractory immuno-mediated uveitis: a non-randomized pilot intervention study. Eye (Lond) 26, 468-77 (2012).

170. Sugita, S., Yamada, Y., Kaneko, S., Horie, S. \& Mochizuki, M. Induction of regulatory T cells by infliximab in Behcet's disease. Invest Ophthalmol Vis Sci 52, 476-84 (2011).

171. Xueyi, L. et al. Levels of circulating Th17 cells and regulatory T cells in ankylosing spondylitis patients with an inadequate response to anti-TNF-alpha therapy. J Clin Immunol 33, 151-61 (2013).

172. Wehrens, E.J. et al. Anti-tumor necrosis factor alpha targets protein kinase B/c-Aktinduced resistance of effector cells to suppression in juvenile idiopathic arthritis. Arthritis Rheum 65, 3279-3284 (2013).

173. Verwoerd, A. et al. Infliximab therapy balances regulatory $\mathrm{T}$ cells, tumour necrosis factor receptor 2 (TNFR2) expression and soluble TNFR2 in sarcoidosis. Clin Exp Immunol 185, 263-70 (2016).

174. Nguyen, D.X. et al. Regulatory T cells as a biomarker for response to adalimumab in rheumatoid arthritis. J Allergy Clin Immunol 142, 978-980 e9 (2018).

175. Chen, X., Oppenheim, J.J., Winkler-Pickett, R.T., Ortaldo, J.R. \& Howard, O.M. Glucocorticoid amplifies IL-2-dependent expansion of functional FoxP3(+)CD4(+)CD25(+) T regulatory cells in vivo and enhances their capacity to suppress EAE. Eur J Immunol 36, 2139-49 (2006).

176. Kim, D. et al. Anti-inflammatory Roles of Glucocorticoids Are Mediated by Foxp3 + Regulatory T Cells via a miR-342-Dependent Mechanism. Immunity 53, 581-596 (2020). 
177. Byng-Maddick, R. \& Ehrenstein, M.R. The impact of biological therapy on regulatory T cells in rheumatoid arthritis. Rheumatology (Oxford) 54, 768-75 (2015).

178. Di Sabatino, A. et al. Peripheral regulatory T cells and serum transforming growth factorbeta: relationship with clinical response to infliximab in Crohn's disease. Inflamm Bowel Dis 16, 1891-7 (2010).

179. Zou, H., Li, R., Hu, H., Hu, Y. \& Chen, X. Modulation of Regulatory T Cell Activity by TNF Receptor Type II-Targeting Pharmacological Agents. Front Immunol 9, 594 (2018)

180. Fischer, R., Kontermann, R.E. \& Pfizenmaier, K. Selective Targeting of TNF Receptors as a Novel Therapeutic Approach. Front Cell Dev Biol 8, 401 (2020).

181. Mukai, Y. et al. Structure-function relationship of tumor necrosis factor (TNF) and its receptor interaction based on 3D structural analysis of a fully active TNFR1-selective TNF mutant. J Mol Biol 385, 1221-9 (2009).

182. Ando, D. et al. Creation of mouse TNFR2-selective agonistic TNF mutants using a phage display technique. Biochem Biophys Rep 7, 309-315 (2016).

183. Van Ostade, X., Vandenabeele, P., Tavernier, J. \& Fiers, W. Human tumor necrosis factor mutants with preferential binding to and activity on either the R55 or R75 receptor. Eur J Biochem 220, 771-9 (1994).

184. McCann, F.E. et al. Selective tumor necrosis factor receptor I blockade is antiinflammatory and reveals immunoregulatory role of tumor necrosis factor receptor II in collagen-induced arthritis. Arthritis Rheumatol 66, 2728-38 (2014).

185. Williams, S.K. et al. Anti-TNFR1 targeting in humanized mice ameliorates disease in a model of multiple sclerosis. Sci Rep 8, 13628 (2018).

186. Steeland, S. et al. TNFR1 inhibition with a Nanobody protects against EAE development in mice. Sci Rep 7, 13646 (2017).

187. Williams, S.K. et al. Antibody-mediated inhibition of TNFR1 attenuates disease in a mouse model of multiple sclerosis. PLoS One 9, e90117 (2014).

188. Zalevsky, J. et al. Dominant-negative inhibitors of soluble TNF attenuate experimental arthritis without suppressing innate immunity to infection. J Immunol 179, 1872-83 (2007).

189. Shibata, H. et al. The treatment of established murine collagen-induced arthritis with a TNFR1-selective antagonistic mutant TNF. Biomaterials 30, 6638-47 (2009).

190. Brambilla, R. et al. Inhibition of soluble tumour necrosis factor is therapeutic in experimental autoimmune encephalomyelitis and promotes axon preservation and remyelination. Brain 134, 2736-54 (2011).

191. Nomura, T. et al. Therapeutic effect of PEGylated TNFR1-selective antagonistic mutant TNF in experimental autoimmune encephalomyelitis mice. $J$ Control Release 149, 8-14 (2011).

192. Taoufik, E. et al. Transmembrane tumour necrosis factor is neuroprotective and regulates experimental autoimmune encephalomyelitis via neuronal nuclear factor-kappaB Brain 134, 2722-2735 (2011).

193. Maier, O., Fischer, R., Agresti, C. \& Pfizenmaier, K. TNF receptor 2 protects oligodendrocyte progenitor cells against oxidative stress. Biochem Biophys Res Commun 440, 336-41 (2013).

194. Rauert, H. et al. Membrane tumor necrosis factor (TNF) induces p100 processing via TNF receptor-2 (TNFR2). J Biol Chem 285, 7394-7404 (2009).

195. Dong, Y. et al. Essential protective role of tumor necrosis factor receptor 2 in neurodegeneration. Proc Natl Acad Sci U S A 113, 12304-12309 (2016).

196. Fischer, R. et al. TNFR 2 promotes Treg-mediated recovery from neuropathic pain across sexes. Proc Natl Acad Sci U S A 116, 17045-17050 (2019). 
197. Klatzmann, D. \& Abbas, A.K. The promise of low-dose interleukin-2 therapy for autoimmune and inflammatory diseases. Nat Rev Immunol 15, 283-94 (2015).

198. Grinberg-Bleyer, Y. et al. IL-2 reverses established type 1 diabetes in NOD mice by a local effect on pancreatic regulatory T cells. J Exp Med 207, 1871-8 (2010).

199. Tang, Q. et al. Central role of defective interleukin-2 production in the triggering of islet autoimmune destruction. Immunity 28, 687-97 (2008).

200. Mori, L., Iselin, S., De Libero, G. \& Lesslauer, W. Attenuation of collagen-induced arthritis in 55-kDa TNF receptor type 1 (TNFR1)-IgG1-treated and TNFR1-deficient mice. J Immunol 157, 3178-82 (1996).

201. Tseng, W.Y. et al. TNF receptor 2 signaling prevents DNA methylation at the Foxp3 promoter and prevents pathogenic conversion of regulatory T cells. Proc Natl Acad Sci U $S$ A 116, 21666-21672 (2019).

202. Bluml, S. et al. Antiinflammatory effects of tumor necrosis factor on hematopoietic cells in a murine model of erosive arthritis. Arthritis Rheum 62,1608-19 (2010).

203. Eugster, H.P. et al. Severity of symptoms and demyelination in MOG-induced EAE depends on TNFR1. Eur J Immunol 29, 626-32 (1999).

204. Suvannavejh, G.C. et al. Divergent roles for $\mathrm{p} 55$ and $\mathrm{p} 75$ tumor necrosis factor receptors in the pathogenesis of MOG(35-55)-induced experimental autoimmune encephalomyelitis. Cell Immunol 205, 24-33 (2000).

205. Kassiotis, G. \& Kollias, G. Uncoupling the proinflammatory from the immunosuppressive properties of tumor necrosis factor (TNF) at the p55 TNF receptor level: implications for pathogenesis and therapy of autoimmune demyelination. $J \operatorname{Exp}$ Med 193, 427-34 (2001).

206. Miller, P.G., Bonn, M.B., Franklin, C.L., Ericsson, A.C. \& McKarns, S.C. TNFR2 Deficiency Acts in Concert with Gut Microbiota To Precipitate Spontaneous Sex-Biased Central Nervous System Demyelinating Autoimmune Disease. J Immunol 195, 4668-84 (2015).

207. Wang, Y.L. et al. Targeting pre-ligand assembly domain of TNFR1 ameliorates autoimmune diseases - an unrevealed role in downregulation of Th17 cells. J Autoimmun 37, 160-70 (2011).

208. Fischer, R. et al. Exogenous activation of tumor necrosis factor receptor 2 promotes recovery from sensory and motor disease in a model of multiple sclerosis. Brain Behav Immun 81, 247-259 (2019). 